\title{
Facility Effluent Monitoring Plan for the Plutonium Finishing Plant
}

Prepared for the U.S. Department of Energy

Assistant Secretary for Environmental Management

Project Hanford Management Contractor for the

U.S. Department of Energy under Contract DE-AC06-96RL13200

Fiver Hanford

P.O. Box 1000

Richland, Washington 


\section{INFORMATION CLEARANCE FORM}

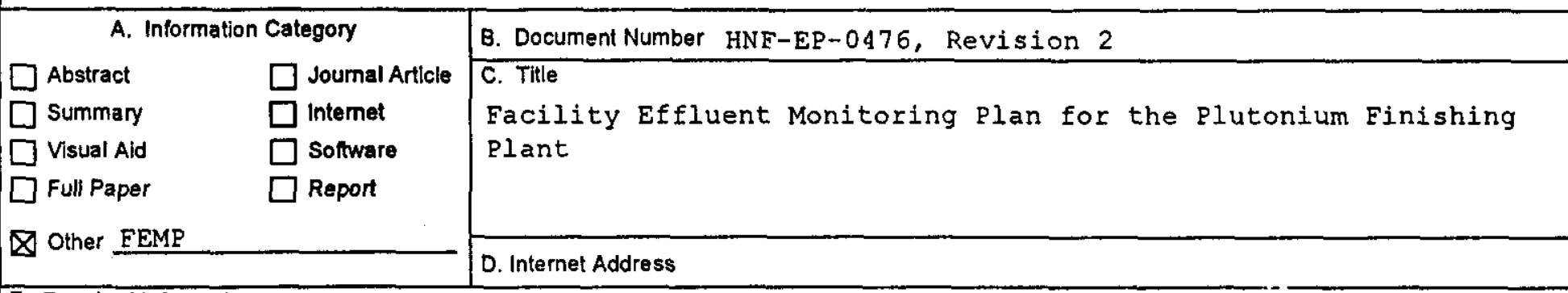

E. Required Information

1. is document potentlally classified? ONo OYes (MANDATORY)

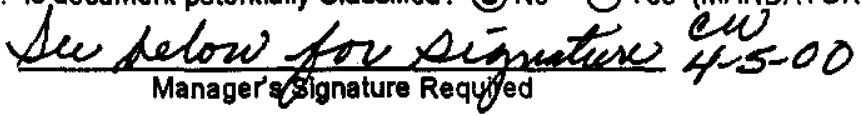

If Yes

Ono OYes classified ADC Signature Required

2. Internal Review Required? If Yes, Document Signatures Below

ONo OYes

Counsel.

Program

3. References in the Information are Applied Technology ONo OYes Export Controlled information Ono Ores
4. Does Information Contain the Foltowing: (MANDATORY)

a. New or Novel (Patentable) Subject Matter? (2) No OYes If "Yes", Disclosure No.:

b. Information Received in Confidence, Such is Prisprietary and/or Inventions? ONo OYes if "Yes", Affix Appropriate Legends/Notices.
c. Copyrights?
Ono OYes
d. Trademarks?
No
OYes
If "Yos". Attach Permission. If "Yes", Identify in Document.

5. Is Information requiring submission to OSTI? $O$ No $O$ Yes If Yes UCand $B \& R-$

6. Release Level? $\bigcirc$ Public $\bigcirc$ Limited

7. Charge code $4328-122 \quad 100019 / 0420$

F. Complete for a Journal Article

1. Title of Joumal

G. Complete for a Presentation

1. Title for Conference or Meeting

2. Group Sponsoring

3. Date of Conference

4. City/State

5. Will Information be Published in Proceedings? $\mathrm{Na} O$ Yes

6. Will Material be Handed Out? $\bigcirc$ No $O$ res:

H. Author/Requestor

Responsible Manager

$\frac{\text { Hox } \rho \text { Iragzer phe }}{\text { (Print and Sign) }}$

General Counse

Office of External Affairs

DOE-RL

Other-LMSI
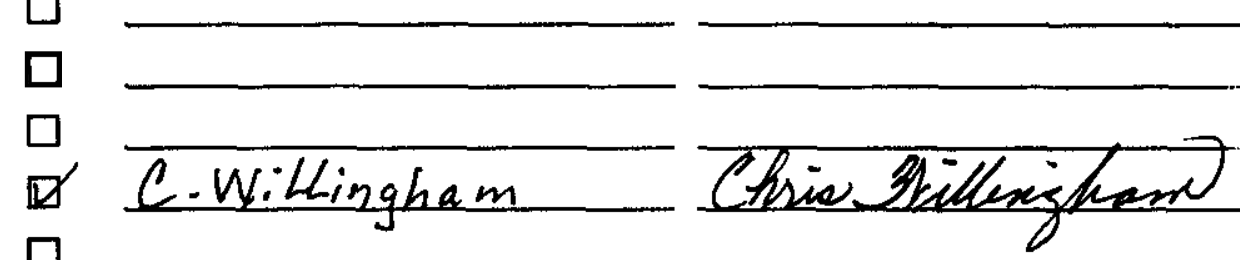

Public Y/N (If N, complete J)

Other

\section{D) S.WiLlingham}

$\square$
$\mathrm{Y} / \mathrm{N}$

$\mathrm{Y} / \mathrm{N}$

$\mathrm{Y} / \mathrm{N}$

Y) $N$

$\mathrm{Y} / \mathrm{N}$

J. If Information Includes Sensitive Information and is not to be released to the Public indicate category below.

$\square$ Applied Technology $\square$ Protected CRADA

$\square$ PersonalPrivate $\square$ Export Controlled

$\square$ Proprietary

$\square$ Business-Sensitive

$\square$ Procurement-Sensitive

$\square$ Predecisiona!

$\square$ Patentable

$\square$ UCNI

$\square$ Other (Specify)

K. If Additional Comments, Please Attach Separate Sheet

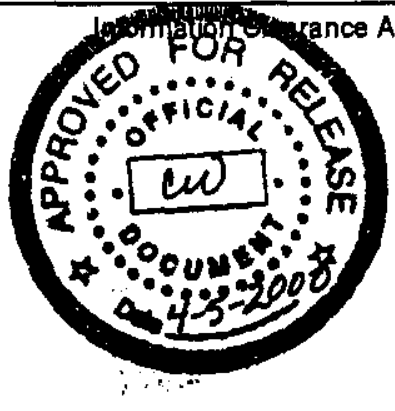


HNF-EP-0467-2

APPROVAL PAGE

Facility Effluent Monitoring Plan for the Plutonium Finishing Plant

Prepared by:

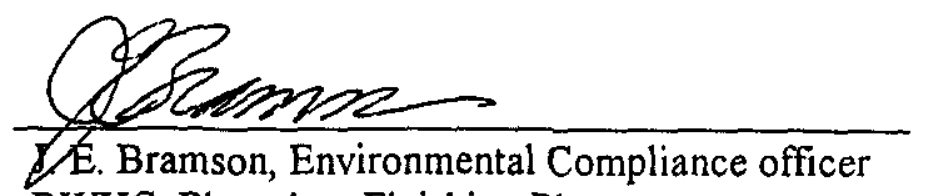

BWHC, Plutonium Finishing Plant

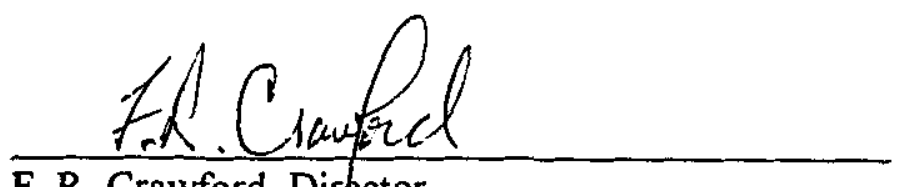

F. R. Crawford, Director, BWHC, PFP Project

T. P.ifr $9-24-99$ Reviewed By:

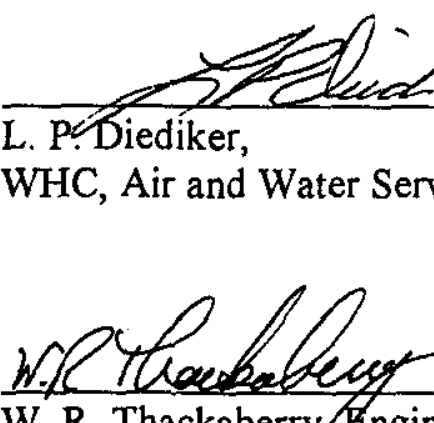

W. R. Thackaberry Engineer WMH, Quality Assurance

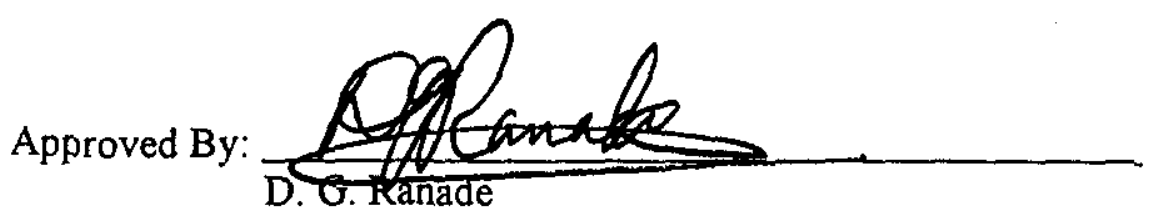

FDH, Environmental Protection $\frac{23501999}{\text { Date }}$

$\frac{9 / 23 / 49}{\text { Date }}$

$\frac{4-24-99}{\text { Date }}$

$\frac{9-29.99}{\text { Date }}$

$\frac{9-29-99}{\text { Date }}$

page $2 g^{2}$ 
HNF-EP-0476

Revision 2

\section{Facility Effluent Monitoring Plan for the Plutonium Finishing Plant}

T.P. Frazier

Fluor Hanford, Inc.

Date Published

October 1999

Prepared for the U.S. Department of Energy

Assistant Secretary for Environmental Management

Project Haniord Management Contractor for the

U.S. Department of Energy under Contract DE-AC06-96RL13200

Fuer Manford

P.O. Box 1000

Richlend, Washington

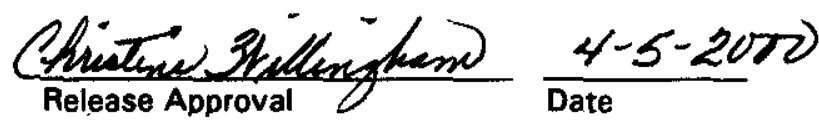




\title{
LECAL DISCLAIMER
}

\begin{abstract}
This report was prepared as an account of work sponsored by an agency of the United States Government. Nelther the United States Government nor any agency thereof, nor any of their employees, nor any of their contractors, subcontractors or their employees, makes any warranty, expreses or implied, or aseume any legal llablilty or reaponeibility for the accuracy, completeneas, or any third party's use or the results of such use of any information, apparatus, product, or process disclosed, or represents that lis use would not infringe privately owned rights. Reference herein to any specific commercial product, process, or service by trade name, trademark, manufacturer, or otherwise, does not necessarlly constitute or Imply its endorsement, recommendation, or favoring by the United States Government or any agency thereof or its contractors or subcontractors. The views and opinions of authore expreased herein do not necessarily state or reflect those of the United States Government or any agency thereof.
\end{abstract}

This report has been reproduced from the beet available copy. 
HNF-EP-0467-2

\section{APPROVAL PAGE}

Facility Emuent Monitoring Plan for the Plutonium Finishing Plant

Prepared by:

F. R. Crawford, Director,

BWHC, PFP Project
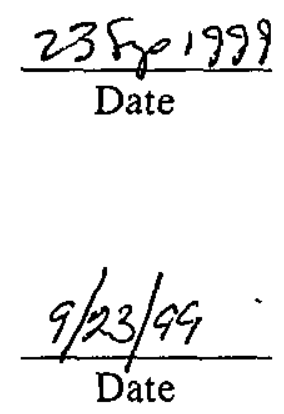

$9-29.99$

Date

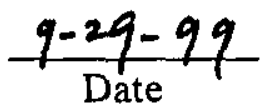

$\frac{9-3 p-99}{\text { Date }}$

D. G. Fanade

L. P. Diediker,

WHC, Air and Water Services

W. R. Thackaberry, Engineer

WMH, Quality Assurance

Approved By:

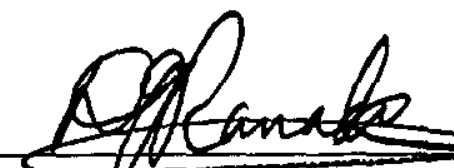

FDH, Environmental Protection 


\title{
FACILITY EFFLUENT MONITORING PLAN FOR THE PLUTONIUM FINISHING PLANT
}

\begin{abstract}
A facility effluent monitoring plan is required by the U. S. Department of Energy in DOE Order $5400.1^{\prime}$ for any operations that involve hazardous materials and radioactive substances that could impact employee or public safety or the environment. This facility effluent monitoring plan assesses effluent monitoring systems and evaluates whether these systems are adequate to ensure the public health and safety as specified in applicable federal, state, and local requirements.

To ensure the long-range integrity of the effluent monitoring systems, an update to this facility effluent monitoring plan is required whenever a new process or operation introduces new hazardous materials or significant radioactive materials. This document is reviewed annually even if there are no operational changes, and is updated, at a minimum, every 3 years.
\end{abstract}

' DOE Order 5400.1, General Environmental Protection Program. 
HNF-EP-0476 Rev. 2

This page intentionally left blank. 


\section{CONTENTS}

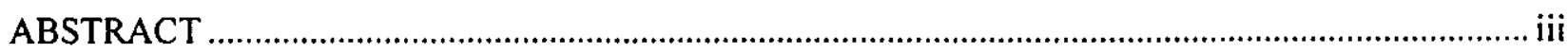

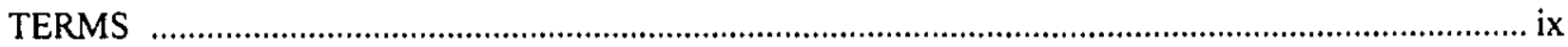

GLOSSARY

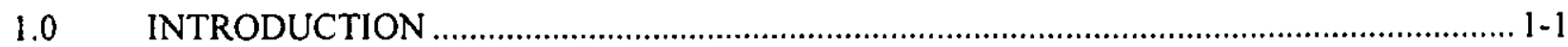

1.1 POLICY

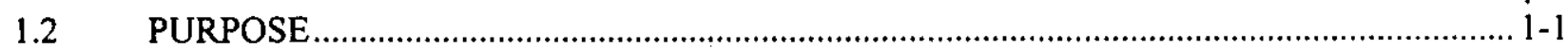

1.3 SCOPE

1.4 DISCUSSION

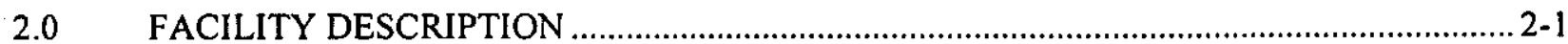

$2.1 \quad$ BRIEF FACILITY PHYSICAL DESCRIPTION ....................................................... 2-1

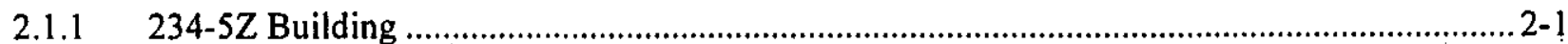

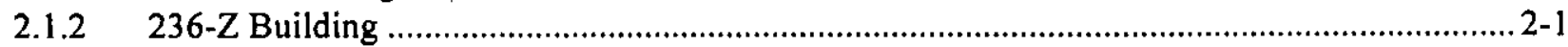

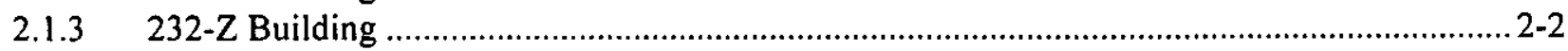

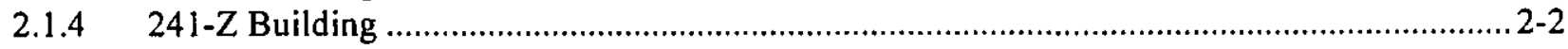

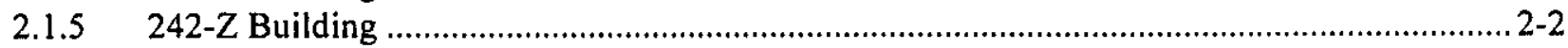

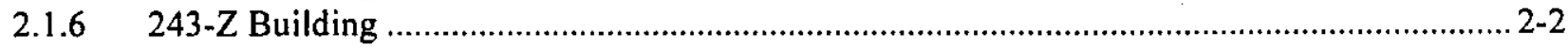

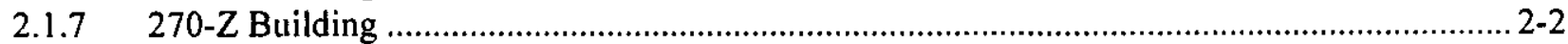

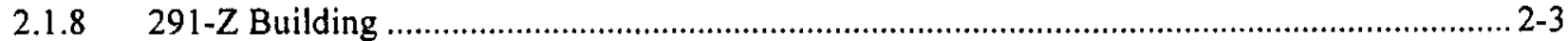

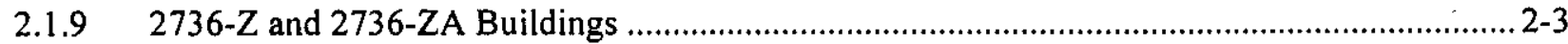

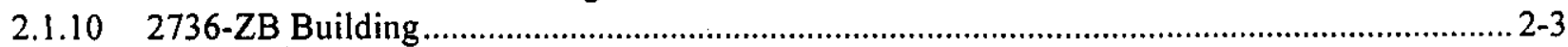

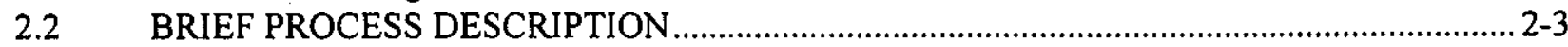

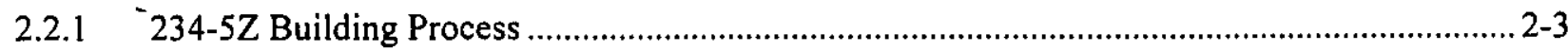

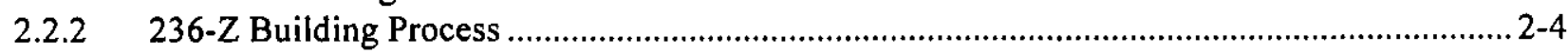

2.2.3 232-Z, 242-Z, and 291-Z Building Processes .............................................................. 2-4

$2.2 .4 \quad 243-Z$ Building Process ............................................................................................. 2-4

2.3 IDENTIFICATION AND CHARACTERIZATION OF POTENTIAL SOURCE TERMS ..... 2-4

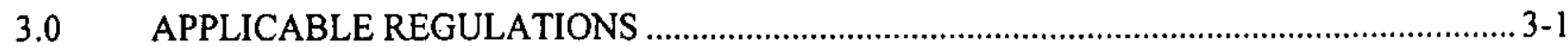

3.1 U.S. DEPARTMENT OF ENERGY ORDERS ……….............................................. 3-1

3.2 FEDERAL REGULATIONS ...........................................................................

3.2.1 National Emission Standards for Hazardous Air Pollutants (40 CFR 61) ................................ 3-1

3.2.2 State Operating Permit Program (40 CFR 70) ……............................................................ 3-3

3.2.3 Identification and Listing of Hazardous Waste (40 CFR 261) ................................................ 3-3

3.2.4 Designation, Reportable Quantities, and Notification (40 CFR 302) ..................................... 3-4

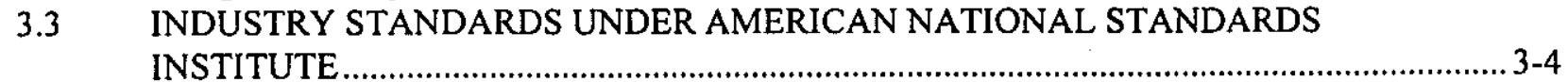

3.4 WASHINGTON STATE REGULATIONS …….......................................................

3.4.1 Air Operating Permit Program (WAC 173-401) .................................................................... 3-4

3.4.2 Ambient Air Quality Standards and Emission Limits for Radionuclides (WAC 173-480)........3-4

3.4.3 Radiation Protection - Air Emissions (WAC 246-247) ......................................................... 3-5

3.4.4 State Waste Discharge Permit Program (WAC 173-216) ………….................................... 3-5

3.4.5 Dangerous Waste Regulations (WAC 173-303) ………............................................................. 3-5

3.5 LOCAL REGULATIONS …………………............................................................... 


\section{CONTENTS (cont)}

4.0 IDENTIFICATION AND CHARACTERIZATION OF EFFLUENT STREAMS .................. 4-1

4.1 291-Z-1 MAIN STACK ROUTINE OPERATING CONDITIONS …..................................... 4-1

4.2 291-Z-1 MAIN STACK UPSET OPERATING CONDITIONS ….................................. 4-2

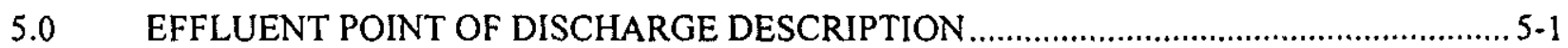

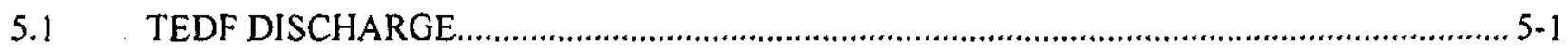

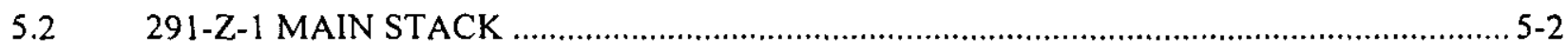

6.0 EFFLUENT MONITORING/SAMPLING SYSTEM DESIGN CRITERIA ..................... 6-1

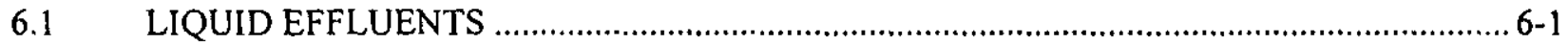

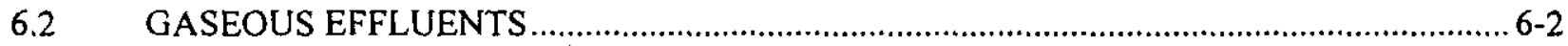

7.0 CHARACTERIZATION OF CURRENT EFFLUENT MONITORING SYSTEM ................. 7-1

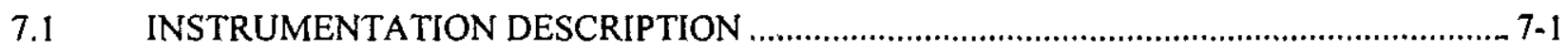

7.2 TECHNICAL SPECIFICATIONS PERTAINING TO THE EFFLUENT MONITORING

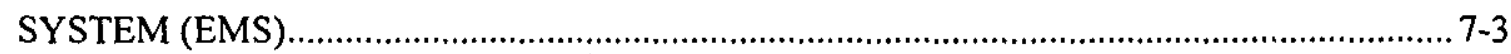

8.0 HISTORICAL MONITORING/SAMPLING DATA FOR EFFLUENT STREAMS .............. 8-1

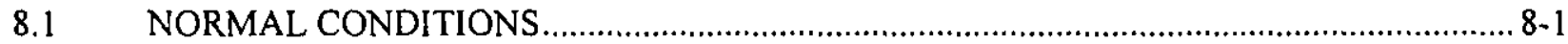

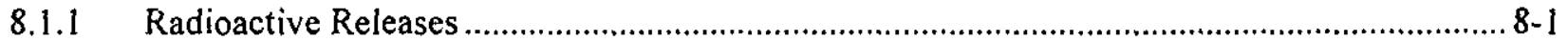

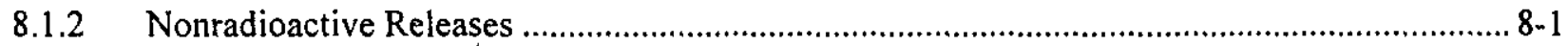

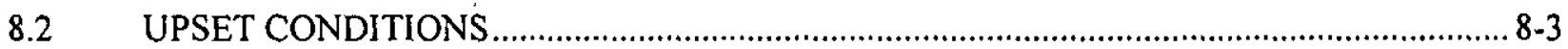

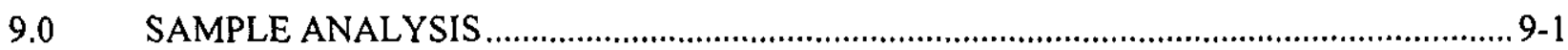

9.1 ANALYTICAL LABORATORY AND PROCEDURES ….......................................... 9-1

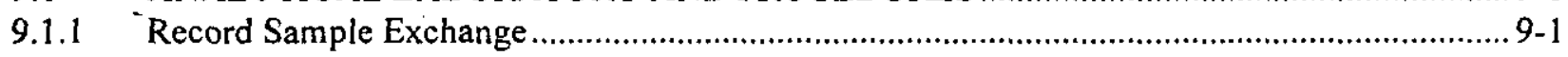

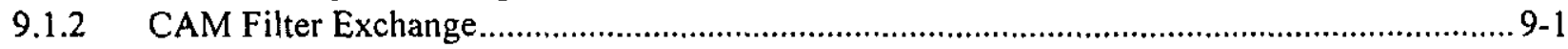

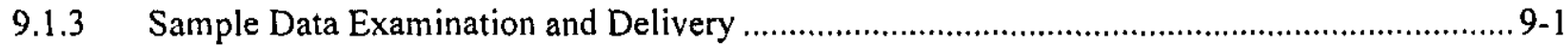

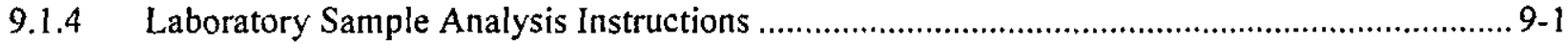

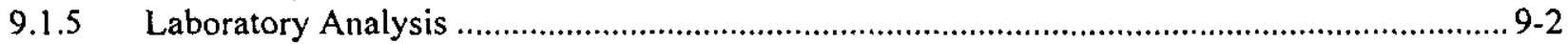

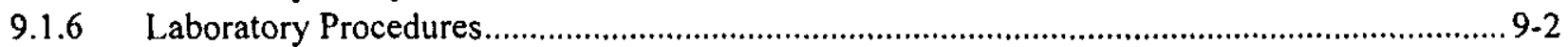

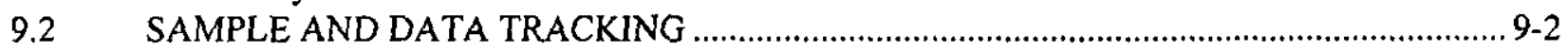

9.3 U.S. DEPARTMENT OF ENERGY ANALYTICAL AND LABORATORY

10.0 NOTIFICATION AND REPORTING REQUIREMENTS _........................................ 10-1

10.1 OCCURRENCE IDENTIFICATION AND IMMEDIATE RESPONSE ........................... 10-1

10.2 OCCURRENCE CATEGORIZATION ..................................................................... 10-1

11.0 INTERFACE WITH NEAR-FACILITY MONITORING ............................................. 11-1

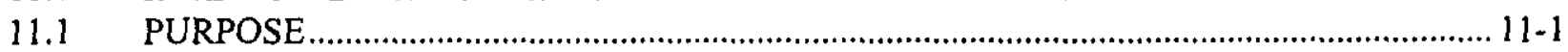

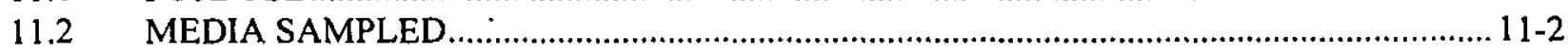

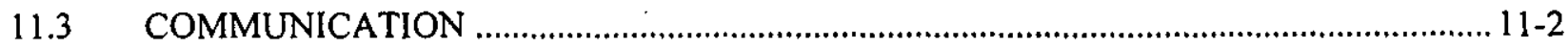

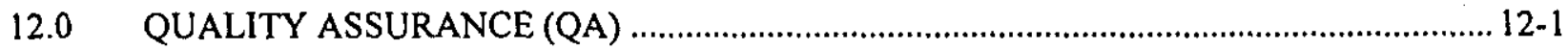

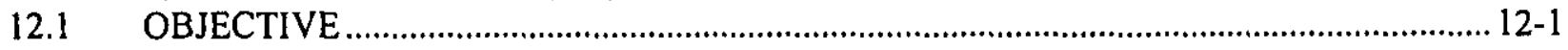

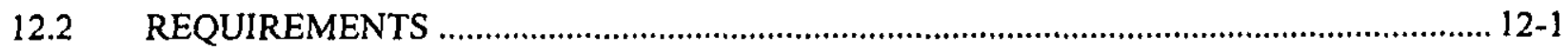


CONTENTS (cont)

13.0 INTERNAL AND EXTERNAL PLAN REVIEW.

14.0 COMPLIANCE ASSESSMENT. $14-1$

15.0 SUMMARY AND CONCLUSIONS $15-1$

16.0 REFERENCES $16-1$

\section{FIGURES}

Figure 2-1. Plutonium Finishing Plant Buildings. F2-1

Figure 5-1. Plan and Overall Piping Schematic for the 200 Area TEDF Effluent Stream F5-1

\section{TABLES}

Table 2-1. Plutonium Finishing Plant Radioactive Material Potential Source Terms. T2-1

Table 2-2. Plutonium Finishing Plant Hazardous Material Potential Source Terms. $\mathrm{T} 2-2$

Table 4-1. Plutonium Finishing Plant Complex Liquid Effluent Streams. T4-1

Table 4-2. Plutonium Finishing Plant Complex Gaseous Effluent Streams. T4-2

Table 7-1. Plutonium Finishing Plant Stack Continuous Air Monitor Operability Requirements.....T7-1

Table 7:2. Monitoring Instrumentation for Gaseous Effluent System, 291-Z-1 Stack T7-2

Table 8-1. Annual Average Concentration (microcuries per milliliter) for 291-Z-1 Stack 1994-1998.T.

Table 8-2. Annual Emissions (Curies) for 291-Z-1 Stack 1994-1998. T8-2

Table 8-3. Hanford Site Dose Estimate For Point Source Emissions. T8-3

Table 9-1. Minimum Quantifiable Concentrations for Specific Radionuclides as Measured in Bi-Weekly Air Samples.

Table 9-2. Data Analyses and Statistical Treatment. 
HNF-EP-0476 Rev. 2

This page intentionally left blank. 


\section{TERMS}

\begin{tabular}{|c|c|}
\hline ABCASH & Automated Bar Coding of Air Samples at Hanford (database) \\
\hline ALARA & as low as reasonably achievable \\
\hline ANSI & American National Standards Institute \\
\hline $\mathrm{BACT}$ & best available control technology \\
\hline BAT & best available technology \\
\hline BAT/AKART & best available technology/all known available reasonable treatment \\
\hline CAM & continuous air monitor \\
\hline CERCLA & Comprehensive Environmental Response, Compensation, and Liability Act of 1980 \\
\hline CFR & Code of Federal Regulations \\
\hline DCG & Derived Concentration Guide \\
\hline DOE & U.S. Department of Energy \\
\hline DOE-RL & U.S. Department of Energy, Richland Operations Office \\
\hline EDE & effective dose equivalent \\
\hline EIS & environmental impact statement \\
\hline EMP & environmental monitoring plan \\
\hline EPA & U.S. Environmental Protection Agency \\
\hline FEMP & facility effluent monitoring plan \\
\hline FFCA & Federal Facility Compliance Agreement \\
\hline $\mathrm{FH}$ & Fluor Hanford \\
\hline HEPA & high-efficiency particulate air \\
\hline HNF & Hanford Nuclear Facility (document identifier) \\
\hline HVAC & heating, ventilation, and air conditioning \\
\hline LLWTF & Low-Level Waste Treatment Facility \\
\hline MEI & maximally exposed individual \\
\hline $\mathrm{MT}$ & miscellaneous treatment \\
\hline NESHÄP & National Emission Standards for Hazardous Air Pollutants \\
\hline NPDES & National Pollutant Discharge Elimination System \\
\hline ONC & Occurrence Notification Center \\
\hline PFP & Plutonium Finishing Plant \\
\hline PNNL & Pacific Northwest National Laboratory \\
\hline PRF & Plutonium Reclamation Facility \\
\hline PSF & Plutonium Storage Facility \\
\hline QAPjP & quality assurance project plan \\
\hline SNM & special nuclear material \\
\hline TEDF & 200 Areas Treated Effluent Disposal Facility \\
\hline VLAW & very low activity wastewater \\
\hline WAC & Washington Administrative Code \\
\hline WHC & Westinghouse Hanford Company \\
\hline WSCF & Waste Sampling and Characterization Facility \\
\hline
\end{tabular}


HNF-EP-0476 Rev. 2

\section{GLOSSARY}

Administrative Control Values. Contractor-imposed radionuclides and hazardous material release limits usually based upon ALARA goals for protection of the public.

Crib. Subsurface liquid waste disposal that allows liquid waste to percolate into surrounding soil.

Dangerous Waste. Washington State designation for solid wastes specified in WAC 173-303-070 through 173-303-103.

Discharge Point or Effluent Discharge Point. The point at which an effluent or discharge enters the environment from the facility in which it was generated.

Effective Dose Equivalent (EDE). The summation of the products of the dose equivalent received by specified tissues of the body and a tissue-specific weighting factor. This sum is a risk-equivalent value and can be used to estimate the health-effects risk of the exposed individual. The tissue-specific weighting factor represents the fraction of the total health risk resulting from uniform whole-body irradiation that would be contributed by that particular tissue. EDE includes the committed EDE from internal deposition of radionuclides and the EDE due to penetrating radiation from sources external to the body. EDE is expressed in units of rem (or sievert).

Effluent. Any treated or untreated air emission or liquid discharge at a DOE site or from a DOE facility.

Effluent Monitoring. Measurement of liquid and gaseous effluents for the purpose of characterizing and quantifying contaminants, assessing radiation exposures of members of the public, providing a means to monitor and/or control effluents at or near the point of discharge, and demonstrating compliance with applicable standards and permit requirements.

Effluent Sampling. The continuous or intermittent collection and analysis of effluent samples for the purpose of characterizing and quantifying contaminants, assessing radiation exposures of members of the public, providing a means to control effluents at or near the point of discharge, and demonstrating compliance with applicable standards and permit requirements.

Environmental Control Limits. Limits based on permit limits and onsite policies as derived from DOE requirements.

Environmental Occurrence. Any sudden or sustained deviation (categorized as emergencies, unusual occurrences, or off-normal occurrences) from a regulated or planned performance at a DOE operation that has environmental protection and compliance significance. Typical occurrences of interest to this document include failure of primary or secondary facility effluent monitoring equipment or a monitored/unmonitored release of regulated materials exceeding administrative control values.

Environmental Surveillance. The collection and analysis of samples, or direct measurements, of air, water, soil, foodstuffs, biota, and other media from DOE sites and their environs for the purpose of determining compliance with applicable standards and permit requirements, assessing radiation exposures of members of the public, and assessing the effects, if any, on the local environment.

Hazardous Substance or Material. Solid, liquid, or gaseous material as defined by the following regulations: 
- Any CERCLA hazardous substance identified in 40 CFR 302.4

- Any Superfund Amendments and Reauthorization Act extremely hazardous substance identified in Appendix A of 40 CFR 355

- Any dangerous waste regulated pursuant to WAC Chapter 173-303, "Dangerous Waste Regulations.

Hazardous Waste. Solid wastes designated by 40 CFR Part 261 , and regulated as hazardous wastes by the EPA or WAC 173-303. This term includes dangerous waste, extremely hazardous wastes, and toxic dangerous waste.

In-line Monitor. A system in which a detector or other measuring device is placed in the effluent stream for performing measurements on the effluent stream.

Inventory at Risk. The quantity and/or type of radioactive and/or nonradioactive hazardous material present in a facility with the potential to enter a gaseous or liquid effluent stream.

Isokinetic. A condition that exists when the velocity of air entering a sampling probe held in an airstream is identical to the velocity axis of flow of the airstream being sampled at that point.

Mixed Waste. Waste containing both radioactive and hazardous components regulated by the Atomic Energy Act of 1954 and the Resource Conservation and Recovery Act of 1976, respectively.

Noncomplexed. Waste that does not contain the chelating agents ethylenediaminetetraacetic acid, hydroxyethylethylenediaminetriacetic acid, citric acid, or hydroxyacetic acid.

Nonconformance. A nonconformance exists when any of the following have occurred, and the appropriate recovery actions are implemented:

- Exceeding an environmental control limit

- Failure to meet an environmental surveillance requirement

- Failure to implement an environmental administrative control

- Failures of primary environmental monitoring equipment to pass a surveillance check.

Normal Operations. A plant operating condition where all processes and safety control devices are operating as designed.

Occurrence Report. A written evaluation of an event or condition that is prepared in sufficient detail to enable the reader to assess its significance, consequences, or implications and to evaluate the actions being proposed or employed to correct the condition or to avoid recurrence.

Plutonium Finishing Plant. As used in this report, the PFP includes the entire complex, which includes the primary processing facility and the ancillary and support buildings. The primary processing facility is referred to as PFP.

Primary Environmental Monitors. Monitoring equipment legally required to monitor ongoing discharges. In general, this term applies to monitors closest to the point of discharge which are used to determine if discharges are within specified limits. 
Radioactive Component. Refers only to the actual radionuclides dispersed or suspended in the waste substance.

Releases. Any spilling, leaking, pumping, pouring, emitting, emptying, discharging, injecting, escaping, leaching, dumping, or otherwise disposing of substances into the environment. This includes abandoning/discarding any type of receptacle containing substances or the stockpiling of a reportable quantity of a hazardous substance in an unenclosed containment structure.

Reportable Quantities. That quantity of hazardous substances as listed in 40 CFR 302 that, if released, requires notification as per 40 CFR 302 . These quantities also provide a criteria for requiring FEMPs with respect to nonradioactive hazardous substances.

Riser. A pipe connected to the top of an underground storage tank or waste pipeline and extended to the surface of the ground. Pumps and instruments are inserted into a waste tank or pipe through a riser.

Secondary Environmental Monitors. Environmental monitoring equipment or activities that, if degraded, will produce a more than minor disruption of a monitoring program. An example of a minor effect . would be the failure of a unit whose place in the program effectively is duplicated by overlap between one or more components.

Shutdown Condition. A condition where all processes involving radioactive and/or hazardous materials are inactive and otherwise stable.

Source Term. The amount, activity, or concentration and the effective release height of a hazardous or radioactive material in a facility effluent stream at the point of discharge that is available for exposure to personnel either within the facility or beyond the site boundary.

Statistically Significant Increase. When used in reference to a continuous release of a hazardous substance listed in 40 CFR 302.4, this term refers to the largest 5 percent of all continuous releases. Determination of statistical significance is based on any of the following:

- Non-parametric statistical test

- Control chart or student $t$ test

- Other tests that have equivalent sensitivity to (a) or (b).

Tank Farm. An area of underground tanks designed to store high-level liquid wastes generated by the reprocessing of nuclear fuel.

Toxic Dangerous Wastes. Designation for waste meeting the criteria specified in WAC 173-303-101.

Transuranic. Any radionuclide having an atomic number greater than 92 .

Underground Injection. Subsurface emplacement of fluids through a bored, drilled, or driven well or through a drywell where the depth of the drywell is greater than the largest surface dimension.

Upset Condition. Any one condition that is outside the normal process operating parameters, or an unusual operating condition where one material confinement/containment barrier or engineered or administrative control has failed. 


\section{FACILITY EFFLUENT MONITORING PLAN FOR THE PLUTONIUM FINISHING PLANT}

\subsection{INTRODUCTION}

This document is prepared to meet U.S. Department of Energy (DOE) Order 5400.1 requirements that a facility effluent monitoring plan (FEMP) exists for each site, facility, or process that uses, generates, releases, or manages significant pollutants of radioactive or hazardous materials that could affect public and personnel safety and the environment. This document is specifically intended to meet this requirement for PFP.

\subsection{POLICY}

It is the policy of the DOE and the Fluor Hanford (FH) to conduct effluent monitoring to determine . whether the public and the environment adequately are protected during DOE operations and whether operations are in compliance with DOE and other applicable federal, state, and local emission standards and requirements. It is also the policy of DOE and $\mathrm{FH}$ that effluent monitoring programs meet high standards of quality and credibility and comply with federal, state, and local emission standards and requirements.

\subsection{PURPOSE}

The purpose of this FEMP is to assess the magnitude of routine and potential liquid and airborne effluent releases from the PFP to determine the compliance of effluent monitoring systems and sampling programs with applicable federal, state, and local regulations.

\subsection{SCOPE}

The scope of this document includes program plans for monitoring and characterizing radioactive and nonradioactive hazardous materials discharged in the PFP complex effluents. This FEMP includes complete documentation for both gaseous and liquid effluent monitoring systems that monitor radioactive and nonradioactive hazardous pollutants that could be discharged to the environment under routine and/or upset conditions. This documentation is provided for each facility that uses, generates, releases, or manages significant quantities of radioactive and nonradioactive hazardous materials that could impact public and employee safety and the environment. This FEMP describes the airborne and liquid effluent paths and the associated sampling and monitoring systems of the PFP complex. Sufficient information is provided on the effluent characteristics and the effluent monitoring systems so that a compliance assessment against requirements could be performed. Adequate details are supplied so that radioactive and hazardous material source terms could be related to specific effluent streams that are, in turn, related to discharge points and finally, compared to the effluent monitoring system capability. Details are provided only for those streams determined previously to require a FEMP. 


\subsection{DISCUSSION}

The characterization of the radioactive and nonradioactive hazardous constituents in each effluent stream provides the underlying rationale for the sampling and monitoring programs. The method of characterization discussed in this FEMP identifies potential pollutants at the point of generation and tracks the constituents in effluent streams as these move from the generation point to the point of discharge.

Information is included from the Facility Effluent Monitoring Plan Determination for the 200 Area Facilities (WHC-EP-0440) and the "Facility Effluent Monitoring Plan Determination for the Treated Effluent Disposal Facility" (WHC Correspondence 018C0-95-036), evaluating whether effluents from PFP meet the criteria for requiring a FEMP. The determination was made in accordance with $A$ Guide for Preparing Hanford Facility Effluent Monitoring Plans (WHC-EP-0438-2). The evaluations were based on information obtained in documents, interviews with cognizant engineers, and personal observations.

A FEMP is required if the total projected dose from radionuclides exceeds 0.1 mrem per year effective dose equivalent (EDE) from any one discharge point or if any one regulated material discharged over a 24-hour period from a facility exceeds 100 percent of a reportable quantity (RQ) as listed in 40 Code of Federal Regulations (CFR) 302.4 or is designated a permitted quantity in Washington Administrative Code (WAC) 173-303-70 through 173-303-103. A FEMP also is required if a liquid effluent is regulated by the National Pollutant Discharge Elimination System (NPDES) and contains radionuclides that would cause any person consuming that effluent to receive an EDE greater than 4.0 mrem exposure annually. DOE Orders also require a FEMP evaluation to consider anticipated facility upset conditions.

Pacific Northwest National Laboratory (PNNL) developed data used in this evaluation converting projected radionuclide releases to offsite doses. Airborne releases were assumed to occur from either an 89-meter stack or at ground level from a central location in the 200 West Area. The distance from the 200 West release point to the offsite location was assumed to be 24,000 meters.

Where possible, actual monitoring data were used to project the radiation dose to offsite individuals. When actual data were used, a multiplication factor of 3,000 for each stage of high-efficiency particulate air (HEPA) filtration was applied to calculate unabated emissions from gaseous effluent systems that normally were filtered with HEPA filters. This was consistent with the U.S. Environmental Protection Agency (EPA) requirement that no pollution control equipment be considered in estimating radionuclide release rates ( 40 CFR 61). Where no actual monitoring data existed, the best available source term data were used. Also where possible, individual radionuclides were used to calculate radiation doses. In some cases, only total alpha and total beta figures were available. In those cases, plutonium-239 and strontium- 90 were used to represent total alpha and beta, respectively.

Based on the calculated unabated emissions EDE exceeding $0.1 \mathrm{mrem}$, gaseous effluent from the 291-Z-1 Main Stack, one PFP effluent stream was identified as requiring a FEMP.

Another stack, 296-Z-15, was determined not to require a FEMP based on its extremely low emission potential (BWHC-9752393). No detectable levels of contamination have been found on the stack sample filters since operation began in May 1994.

The PFP liquid effluent stream, previously identified by the discharge point $216-Z-20 \mathrm{Crib}$, was isolated from the crib and tied into the 200 Areas Treated Effluent Disposal Facility (TEDF) on May 22, 1995. The FEMP determination report (WHC-EP-0440) concluded this stream required a FEMP based on the 
radioactive discharge potential. Following TEDF tie-in, this stream's potential has been re-evaluated. The FEMP determination report for TEDF (WHC Correspondence 018C0-95-036) concluded that a FEMP was not required for the TEDF effluent stream. This was a result of best available technology/all known available reasonable treatment (BAT/AKART) measures taken by the facilities tied into TEDF to meet drinking water standards found in 40 CFR 141. Therefore, the 216-Z-20 effluent stream, formerly included in this FEMP, is no longer considered a stream with the potential to meet the FEMP dose criteria. The following describes controls currently in place for this effluent stream.

Historically PFP had a potential to exceed the derived concentration guide (DCG) for total alpha. Implementation of BAT/AKART through installation of closed-loop cooling and startup of the low-level waste treatment facility (LLWTF) greatly has reduced this potential. Currently, however, measures remain in place to ensure that PFP does not discharge waste to TEDF that exceeds the DCGs. The specific analyses required include total alpha, total beta, plutonium-238, plutonium-239/240, plutonium-241 (calculated), plutonium-241, and gamma energy analysis.

Details of the 291-Z-1 Stack effluent stream, which requires a FEMP, and the associated monitoring and sampling system are included in this FEMP. Limited information on all other effluent streams also is provided.

Two additional effluent streams were designated in WHC-EP-0440 as requiring a FEMP: the 216-Z-13, 216-Z-14, and the 216-Z-15 French drains for the 291-Z Building, and the 2734-ZL heating, ventilation, and air conditioning (HVAC) exhaust for the 2734-ZL Building. The French drains were re-evaluated as not requiring a FEMP, based on the availability of more detailed information on the potential source term. The 2734-ZL Building was re-evaluated as not requiring a FEMP, based on the permanent removal of the source term from the building. 
HNF-EP-0476 Rev. 2

This page intentionally left blank. 


\subsection{FACILITY DESCRIPTION}

Brief descriptions of the physical characteristics of PFP, the primary process, and information with respect to potential process source terms present in this section are provided. Information on certain support buildings also is presented.

\subsection{BRIEF FACILITY PHYSICAL DESCRIPTION}

The PFP Complex, located in the 200 West Area of the Hanford Site, includes a number of operations involved in the recovery and chemical conversion of plutonium. PFP consists of one primary processing building (234-5Z) and several ancillary buildings: $236-Z, 232-Z, 241-Z, 242-Z, 243-Z, 270-Z, 291-Z$, 2736-Z, 2736-ZA, and 2736-ZB. Figure 2-1 shows the arrangement of the PFP Complex.

\subsubsection{4-5Z Building}

PFP, or the 234-5 Building, has approximate dimensions of 180 feet wide by 500 feet long and extends from 9.5 feet belowgrade to 46.8 feet abovegrade. Floor levels are designated as the basement, first floor, duct level, second floor, and roof level. Noncombustible construction materials were used. The frame is of structural steel with an outer sheathing of aluminum panels over rock wool insulation and 16-gauge sheet steel. The first floor is a concrete slab, the duct level is sheet-metal roof decking, and the second floor is a concrete slab. The roof is constructed of insulated metal decking. Interior walls are reinforced concrete steel structure, or metal studs, metal lath, and plaster. The vault and process area doors are constructed of steel with combination safe-type locks. Liquid effluents from the 234-5Z Building that potentially are contaminated are processed in the LLWTF before being discharged to TEDF.

\subsubsection{6-Z Building}

The 236-Z Building, located south of the southeastern corner of the 234-5Z Building, connects to the 242-Z Building. The 236-Z Building houses the Plutonium Reclamation Facility (PRF). Building air is exhausted through the 291-Z-1 Stack. Some liquid effluents from the $236-Z$ Building are processed in the LLWTF and discharged to TEDF. Adding closed-loop cooling systems has eliminated the potentially radioactive contaminated liquid effluents from the $236-Z$ Building. Currently, the PRF process is in shutdown status with decommissioning activities the only planned future operations.

The 236-Z Building, a four-story structure surmounted by a two-story penthouse, is approximately 79 feet wide by 71 feet long. Its outstanding internal structural feature is a single process equipment cell that is 32 feet wide by 52 feet long that extends through the third floor. The building is constructed of reinforced concrete, with the exception of the roof and the fourth floor ceiling. The roof is of open-web steel joist framing, steel decking, rigid insulation, and graveled built-up roofing. A portion of the southern building wall is also the south wall of the process cell and includes an opening in the reinforced concrete wall for moving large equipment. A door and surrounding block wall fill this opening. The concrete block wall has been steel plated and reinforced to withstand seismic effects. 
HNF-EP-0476 Rev. 2

\subsubsection{2-Z Building}

The 232-Z Building houses the layaway contaminated waste recovery process, commonly referred to as the 'Incinerator'. The contaminated waste recovery process currently is undergoing decontamination and decommissioning activities.

The 232-Z Building, a concrete block construction, is 37 feet wide by 57 feet long. The building is divided into areas for process, storage, change room, chemical preparation, ventilation, and electrical equipment. Except for ventilation supply and exhaust filtration, electrical and steam services from the 234-5Z and 291-Z Buildings are used. All drains that discharged liquid to the effluent drain system have been eliminated.

\subsubsection{1-Z Building}

The 241-Z Building, designated as the waste treatment area, is a buried reinforced concrete structure approximately 20 feet wide, 92 feet long, and 22 feet deep, with a sheet-metal enclosure over the top that houses a hoist for removing cell covers. The building consists of five separate enclosures or ventilated cells, each containing a 20,000-liter tank used to accumulate liquid waste before transfer to the Double-Shell Tank System (DST). The building is located approximately 330 feet south of the 234-5Z Building.

At the southwest corner of the $241-Z$ vault deck is the equipment for the vessel vent and vault ventilation system. The 24-foot-high 296-Z-3 Stack and its associated fans, filters, and controls are located on a 14-foot by 18 -foot concrete pad. Building air is exhausted through the 296-Z-3 Stack.

\subsubsection{2-Z Building}

The 242-Z Building houses portions of the waste treatment and americium recovery operations, which are in layaway status and planned for future decontamination and decommissioning.

\subsubsection{3-Z Building}

The 243-Z Building is the LLWTF, a 35 feet by 70 feet corrugated aluminum building located south of the 234-5Z Building. The LLWTF receives very low activity wastewater (VLAW) from various PFP operations via maintenance cover 4 . The VLAW is treated and discharged to maintenance cover 7. Building air is exhausted through the 296-Z-15 Stack located near the northwest corner of the building.

\subsubsection{0-Z Building}

The 270-Z Building, a wood-frame structure with sheetrock inner walls, houses management and engineering personnel. 


\subsubsection{1-Z Building}

The 291-Z Building is a reinforced-concrete structure approximately 74 feet wide by 143 feet long by 23 feet high, with only 4 feet abovegrade, located approximately 53 feet south of the central part of the 234-5Z Building. This building houses the exhaust fans, the mechanical service equipment, and the substation.

Auxiliary to the 291-Z Building is the 200-foot-high 291-Z-1 Stack. Constructed of reinforced concrete, the center of the stack is 63 feet from the near end of the 291-Z Building and 230 feet from the south wall of the 234-5Z Building.

\subsubsection{6-Z and 2736-ZA Buildings}

The 2736-Z Building, the primary plutonium storage facility (PSF), is approximately 65 feet long by 56 feet wide and consists of four rooms for the storage of special nuclear material (SNM), divided by a corridor running the width of the building. The building is constructed of reinforced concrete walls, 14 inch thick, supported by cast-in-place concrete columns. The roof is a cast-in-place 6.5 -inch-thick concrete slab. The 2736 -ZA Building provides ventilation for the $2736-Z$ Building with air from the 2736-Z Building exhausted through the 296-Z-6 Stack located on the roof of the 2736-ZA Building.

\subsubsection{6-ZB Building}

The 2736-ZB Building, located immediately to the south of the 2736-Z Building, is approximately 132 feet by 90 feet with reinforced concrete walls (except for administrative areas) and roof. Air from the 2736-ZB Building is exhausted through the 296-Z-5 Stack, which is located on the roof. The building contains approximately 2,000 square feet of floor space and is used primarily for shipping and receiving plutonium products and miscellaneous solid scrap materials.

\subsection{BRIEF PROCESS DESCRIPTION}

The following is a brief description of the processes that could occur. As a result of these processes, liquid and gaseous effluents are created.

\subsubsection{4-5Z Building Process}

Future operations in the $234-5 Z$ building include processing activities necessary to remove and stabilize plutonium-bearing materials. These operations were described and analyzed in the PFP Stabilization Final Environmental Impact Statement (EIS) (DOE/EIS-0244-F) issued in May 1996, with the Record of Decision (ROD) issued on June 25, 1996. The ROD documents the decision to proceed with a select group of stabilization alternatives identified in the EIS. The following lists the primary stabilization alternatives for each of the plutonium bearing inventory categories as identified in the ROD and described by the EIS:

- Ion exchange, vertical calcination, and thermal stabilization or hydroxide precipitation followed by thermal stabilization for plutonium-bearing solutions 
HNF-EP-0476 Rev. 2

- Batch thermal stabilization using muffle furnaces for oxides, fluorides, and process residues

- Batch thermal stabilization using muffle furnaces and repackaging for metals and alloys

- Pyrolysis or batch thermal stabilization for polycubes and combustibles

- Immobilization via cementation for material with low plutonium content

- Stabilization or immobilization for readily retrievable plutonium-bearing materials that can be removed from ductwork, vacuum system piping, gloveboxes, hoods, and the PRF canyon floor.

\subsubsection{6-Z Building Process}

The 236-Z Building houses the PRF process equipment and services for miscellaneous treatment (MT) slag and crucible dissolution, filtrate concentration, feed preparation, plutonium solvent extraction, product concentration, and waste treatment processes. Currently the only active operations are clean up and material removal required under the EIS ROD.

\subsubsection{2-Z, 242-Z, and 291-Z Building Processes}

The 232-Z, 242-Z, and 291-Z Buildings do not house active processes. The 232- $Z$ Building contains an incinerator facility that is partially decontaminated and dismantled and is being prepared for removal. The 242-Z Building previously housed the waste treatment and americium recovery process. The 291-Z Building houses a substation, mechanical service equipment, and exhaust fans.

\subsubsection{3-Z Building Process}

This water treatment facility was built to support implementation of best available technology/all known and reasonable technology (BAT/AKART) for PFP liquid effluents before discharge to the 200 Area TEDF. Liquid waste is treated for organic, inorganic, and radionuclide contamination by passing the water through a series of filter trains consisting of granular activated carbon, bone char, and ion exchange resins. The purpose of the LLWTF is to produce water suitable for discharge to the 200 Area TEDF, meeting all discharge limits listed in the State Waste Discharge Permit No. ST 4502 for the 200 Area TEDF.

\subsection{IDENTIFICATION AND CHARACTERIZATION OF POTENTIAL SOURCE TERMS}

This section summarizes the potential PFP process source terms. Tables 2-1 and 2-2 summarize the source term information developed in WHC-EP-0440 for both radioactive and hazardous materials. Some of the values presented are different from those in WHC-EP- 0440 because each effluent stream was re-evaluated to incorporate the most recent source term information. 


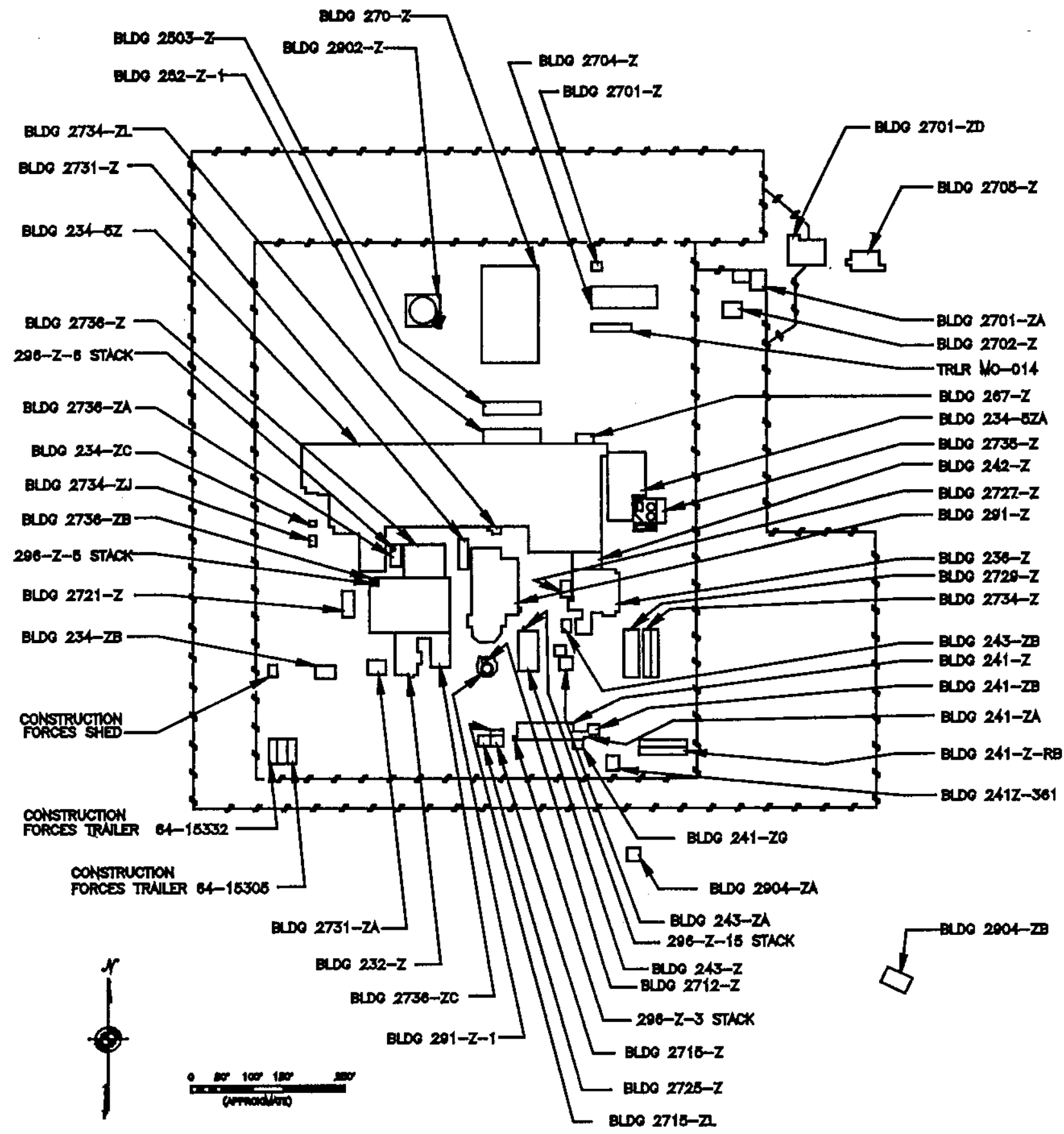

Figure 2-1. Plutonium Finishing Plant Buildings. 
HNF-EP-0476 Rev. 2

This page intentionally left blank. 
HNF-EP-0476 Rev. 2

Table 2-1. Plutonium Finishing Plant Radioactive Material Potential Source Terms.

\begin{tabular}{|c|c|c|c|c|c|}
\hline Radionuclide & Form & Building & Discharge point & $\begin{array}{l}\text { Potential } \\
\text { quantity } \\
\text { released } \\
(\mathrm{Ci} / \mathrm{yr})^{\mathrm{a}}\end{array}$ & $\begin{array}{l}\text { Potential } \\
\text { projected } \\
\text { dose } \\
(\mathrm{mrem} / \mathrm{yr})^{\mathrm{n}}\end{array}$ \\
\hline Pu-239 & Particulate & $234-5 Z, 236-Z, 242-Z$ & 291-Z-1 Main Stack & $1.1 \mathrm{E}+7$ & $1.8 \mathrm{E}+7$ \\
\hline Pu-24l & Particulate & $234-5 Z, 236-Z, 242-Z$ & 291-Z.1 Main Stack & $7.8 \mathrm{E}+7$ & $1.9 \mathrm{E}+6$ \\
\hline$A m-241$ & Particulate & $234-5 Z, 236-Z, 242-Z$ & 291-2-1 Main Stack & $1.9 \mathrm{E}+7$ & $4.6 \mathrm{E}+6$ \\
\hline Total Beta & Particulate & $234-5 Z, 236-Z, 242-Z$ & 291-Z-1 Main Stack & $9.2 \mathrm{E}+7$ & $4.2 \mathrm{E}+3$ \\
\hline Pu-238 & Particulate & $24 !-Z$ & 296-Z-3 Stack & $1.3 \mathrm{E}-4$ & $8.7 \mathrm{E}-4$ \\
\hline $\mathrm{Pu}+239$ & Particulate & $241-Z$ & 296-Z-3 Stack & $4.3 E-3$ & $3.2 E-2$ \\
\hline $\mathrm{Pu}-240$ & Particulate & $241-Z$ & 296-Z-3 Stack & $1.0 \mathrm{E}-3$ & $7.5 \mathrm{E}-3$ \\
\hline Pu-241 & Particulate & $241-Z$ & 296-Z-3 Stack & $2.3 \mathrm{E}-2$ & $3.5 \mathrm{E}-3$ \\
\hline$P u-242$ & Particulate & $241-Z$ & 296-Z-3 Stack & $6.0 E=8$ & $4.8 E-7$ \\
\hline$A m-241$ & Particulate & $241-Z$ & 296-Z-3 Stack & $5.8 \mathrm{E}-4$ & $4.5 \mathrm{E}-3$ \\
\hline Pu-238 & Particulate & $2736-Z B$ & 296-Z-5 Stack & $4.4 \mathrm{~B}-4$ & $2.1 \mathrm{E}-4$ \\
\hline $\mathrm{Pu}-239$ & Particulate & $2736-2 B$ & 296-Z-5 Stack & $1.7 E-3$ & $8.8 \mathrm{E}-3$ \\
\hline Pu-240 & Particulate & $2736-\mathrm{ZB}$ & $296-Z-5$ Stack & $7.8 \mathrm{E}-4$ & $4.0 \mathrm{E}-3$ \\
\hline $\mathrm{Pu}-241$ & Particulate & $2736-\mathrm{ZB}$ & 296-Z-5 Stack & $4.3 \mathrm{E}-2$ & $3.5 \mathrm{E}-3$ \\
\hline$A m-241$ & Particulate & $2736-Z B$ & 296-Z-5 Stack & $1.5 E-3$ & $1.2 \mathrm{E}-2$ \\
\hline $\mathrm{Pu}-238$ & Particulate & $2736-Z, 2736-Z A$ & 296-Z-6 Stack & $1.3 \mathrm{E}-3$ & $6.0 \mathrm{E}-3$ \\
\hline Pu-239 & Particulate & $2736-\mathrm{Z}, 2736-\mathrm{ZA}$ & 296-Z-6 Stack & $1.7 \mathrm{E}-3$ & $8.7 \mathrm{E}-3$ \\
\hline $\mathrm{Pu}-240$ & Particulate & $2736-Z, 2736-\mathrm{ZA}$ & 296-Z-6 Stack & $1.4 \mathrm{E}-3$ & $7.3 \mathrm{E}-3$ \\
\hline Pu-241 & Particulate & $2736-\mathrm{Z}, 2736-\mathrm{ZA}$ & 296-Z-6 Stack & $9.0 \mathrm{E}-2$ & $7.4 \mathrm{E}-3$ \\
\hline Am-241 & Particulate & $2736-Z, 2736-Z A$ & 296-Z-6 Stack & $3.2 \mathrm{E}-3$ & $2.5 \mathrm{E}-2$ \\
\hline $\mathrm{Pu}-238$ & Particulate & $232-Z$ & 296-Z-14 Stack & $6.3 E+6$ & 3.0 E-5 \\
\hline Pu-239 & Particulate & $232-Z$ & 296-Z-14 Stack & $2.5 \mathrm{E}-5$ & $1.3 \mathrm{E}-4$ \\
\hline Pu-240 & Particulate & $232-Z$ & 296-Z-I4 Stack & I.1 E-5 & $5.8 \mathrm{E}-5$ \\
\hline Pu-241 & Particulate & $232-Z$ & 296-Z-14 Stack & $6.1 \mathrm{E}-4$ & $5.0 \mathrm{E}-5$ \\
\hline $\mathrm{Am} \cdot 241$ & Particulate & $232-Z$ & 296-Z-14 Stack & $2.1 \mathrm{E}-5$ & $1.7 \mathrm{E}-4$ \\
\hline
\end{tabular}

$\mathrm{Ci} / \mathrm{yr}=$ curies per year.

$\mathrm{mrem} / \mathrm{ys}=$ millirem per year.

- Potential quantities released and potential projected dose are based on information provided in WHC-EP-0894, and WHC Internal Memo, 15540-94-MPB-164.

'Value calculated using the CAP88 method (HNF-3602, Vol. 1).

NOTE: No detectable levels of contamination have been found on the 296-Z-15 Stack sample filters for 243-Z Building.

NOTE: For annual emissions (Ci) for the 291-Z Stack, refer to Table 8-2. 
Table 2-2. Plutonium Finishing Plant Hazardous Material Potential Source Terms.

\begin{tabular}{|l|l|l|c|c|}
\hline \multicolumn{1}{|c|}{ Chemical } & \multicolumn{1}{|c|}{ Building } & Discharge point & $\begin{array}{c}\text { Releasable } \\
\text { quantity (lb/day) }\end{array}$ & $\begin{array}{c}\text { Reportable } \\
\text { quantity (lb/day) }\end{array}$ \\
\hline $\mathrm{NO}_{\mathrm{X}}$ & $234-5 \mathrm{Z}, 236-\mathrm{Z}$ & $291-\mathrm{Z}-1$ Main Stack & $<10^{\mathrm{a}}$ & 10 \\
\hline $\mathrm{NO}_{\mathrm{X}}$ & $234-5 \mathrm{Z}, 236-\mathrm{Z}$ & $291-\mathrm{Z}-1$ Main Stack & $>10^{\mathrm{b}}$ & 10 \\
\hline $\mathrm{HCI}$ & $234-5 \mathrm{Z}, 236-\mathrm{Z}$ & $291-\mathrm{Z}-1$ Main Stack & $20 /$ year & 5,000 \\
\hline Acetone & $234-5 \mathrm{Z}, 236-\mathrm{Z}$ & $291-\mathrm{Z}-1$ Main Stack & $<10^{\mathrm{b}}$ & 5,000 \\
\hline $\mathrm{NO}_{\mathrm{X}}$ & $241-\mathrm{Z}$ & $296-\mathrm{Z}-3$ Stack & $<10^{\mathrm{b}}$ & 10 \\
\hline
\end{tabular}

$\mathrm{Ib} /$ day $=$ pounds per day.

- releasable quantities based on information provided in WHC-EP-0440 and updated in this report.

${ }^{b}$ Upset condition. 
HNF-EP-0476 Rev. 2

\subsection{APPLICABLE REGULATIONS}

Conditions and requirements for monitoring existing or potential releases of radioactive and other chemicals to the environment are contained in DOE Orders and federal, state, and local laws, regulations, and permits. Table 3-1 gives a brief summary of the regulations and standards applicable to this FEMP. Because the regulations enforced by these agencies can differ, more restrictive requirements could be enforced as a matter of policy.

\subsection{U.S. DEPARTMENT OF ENERGY ORDERS}

DOE Order 5400.1, General Environmental Protection Program, requires a written environmental monitoring plan for each site, facility, or process that uses, generates, releases, or manages significant pollutants or hazardous materials. The plan must include the rationale and design criteria for the monitoring program, as well as describe the extent and frequency of the monitoring analysis. The plan also must contain quality assurance requirements, program implementation procedures, directions for. preparation and implementation of reports, and directions for identification and discussion of effluent monitoring and environmental surveillance.

The effluent monitoring portion of the plan must verify compliance with applicable regulations and DOE Orders. The plan also should evaluate the effectiveness of treatment; identify potential environmental problems; evaluate the need from remedial action or mitigation measures; support permit revision and/or reissuance; and detect, characterize, and report unplanned releases.

DOE Order 5400.5, Radiation Protection of the Public and the Environment, requires a monitoring plan that complies with the requirements of DOE Order 5400.1. Compliance with the requirements of DOE Order 5400.5 could be demonstrated based on calculations from monitoring and surveillance programs.

DOE Order 5820.2A, Radioactive Waste Management, establishes policies, guidelines, and minimum requirements by which the DOE manages radioactive and mixed waste and contaminated facilities.

\subsection{FEDERAL REGULATIONS}

Federal regulations applicable to this FEMP are discussed in the following sections.

\subsubsection{National Emission Standards for Hazardous Air Pollutants (40 CFR 61)}

Subpart H, "National Emission Standards for Emissions of Radionuclides Other Than Radon from Department of Energy Facilities" (40 CFR 61), establishes exposure limits and monitoring requirements. The exposure limit for members of the public from radionuclide emissions is an EDE not to exceed 10 mrem per year. Compliance with this standard is measured by calculating the highest EDE where a person resides or abides using an EPA-approved method.

Emissions of radionuclides must be measured at all release points that have a potential to discharge radionuclides into the air in quantities that could cause an EDE in excess of 1 percent of the standard. If the EDE caused by all emissions is less than 1 percent of the standard, a facility is exempt from the EPA monitoring requirements. All radionuclides that could contribute greater than 10 percent of the potential 
EDE for a release point are measured individually. For other release points that have a potential to release radionuclides into the air, periodic confirmatory measurements are made to verify low emissions.

To determine whether a release point is subject to emission measurement requirements, the potential for radionuclide emissions for that release point must be evaluated. In evaluating the potential of a release point to discharge radionuclides into the air, the estimated radionuclide release rates are based on the discharge of the effluent stream that would result if all pollution control equipment did not exist, but operations otherwise were normal..

Subpart $\mathrm{H}$ also states that effluent streams be directly monitored continuously with an in-line detector or that representative samples of the effluent stream be withdrawn continuously from the sampling site following the guidance presented in American National Standards Institute (ANSI) N13.1. The EPA also has approved an Alternate Method for sampling using single point sampling with a shrouded probe. The requirements for continuous sampling are applicable to batch processes when the unit is in operation. Periodic sampling (grab samples) could be used only with prior EPA approval. Such approval could be granted in cases where continuous sampling is not practical and radionuclide emission rates are relatively constant. In such cases, grab samples will be collected with sufficient frequency to provide a representative sample of the emissions.

\begin{tabular}{|c|c|c|c|}
\hline Agency/originator & Regulation, standard, or permit & $\begin{array}{l}\text { Applicable to } \\
\text { facility }\end{array}$ & Summary/application \\
\hline \multirow[t]{4}{*}{$\begin{array}{l}\text { DOE, } \\
\text { Washington, D.C. }\end{array}$} & $\begin{array}{l}\text { DOE Order } 5400.1, \text { General } \\
\text { Environmental Protection Program }\end{array}$ & $\mathrm{X}$ & $\begin{array}{l}\text { Provides general environmental protection } \\
\text { standards }\end{array}$ \\
\hline & $\begin{array}{l}\text { DOE Order } 5400.5, \text { Radiation } \\
\text { Protection of the Public and } \\
\text { Environment }\end{array}$ & $\bar{X}$ & $\begin{array}{l}\text { Sets radioactive release standards for the } \\
\text { public and environment (dose limits) }\end{array}$ \\
\hline & $\begin{array}{l}\text { DOE Order } 5820.2 \mathrm{~A}, \text { Radioactive } \\
\text { Waste Management }\end{array}$ & $\mathrm{X}$ & $\begin{array}{l}\text { Sets radioactive waste management } \\
\text { requirements ( } 10 \text { CFR } 835 \text { requires } \\
\text { monitoring for outdoor contamination near } \\
\text { facility) }\end{array}$ \\
\hline & $\begin{array}{l}\text { DOE/EH-0173T, Environmental } \\
\text { Regulatory Guide for Radiological } \\
\text { Effuent Monitoring and Environmental } \\
\text { Surveillance }\end{array}$ & $\bar{X}$ & $\begin{array}{l}\text { Provides guidance for effluent sampling and } \\
\text { monitoring }\end{array}$ \\
\hline \multirow[t]{7}{*}{$\begin{array}{l}\text { EPA, } \\
\text { Washington, D.C. }\end{array}$} & $\begin{array}{l}40 \text { CFR } 60 \text {, "Standards of Performance } \\
\text { for New Stationary Sources" }\end{array}$ & $\mathrm{X}$ & $\begin{array}{l}\text { Establishes monitoring requirements for air } \\
\text { pollutants }\end{array}$ \\
\hline & 40 CFR 61, NESHAP & $\overline{\mathrm{X}}$ & $\begin{array}{l}\text { Sets national emission standards for } \\
\text { hazardous air pollutants (NESHAP) }\end{array}$ \\
\hline & $\begin{array}{l}40 \text { CFR } 61, \text { Subpart A, "General } \\
\text { Provisions" }\end{array}$ & $\mathrm{X}$ & Regulates hazardous pollutants \\
\hline & $\begin{array}{l}40 \text { CFR } 61 \text {, Subpart H, "NESHAP for } \\
\text { Radionuclides other than Radon from } \\
\text { Department of Energy Facilities" }\end{array}$ & $\bar{X}$ & $\begin{array}{l}\text { Sets emissions standards/monitoring } \\
\text { requirements for radionuclides }\end{array}$ \\
\hline & $\begin{array}{l}40 \text { CFR 70, "State Operating Permit } \\
\text { Program" }\end{array}$ & $\bar{X}$ & $\begin{array}{l}\text { Requires state air operating permit programs } \\
\text { (i.e., WAC 173-401) }\end{array}$ \\
\hline & $\begin{array}{l}40 \text { CFR 261, "Identification and Listing } \\
\text { of Hazardous Waste" }\end{array}$ & $\mathrm{X}$ & Identifies and lists hazardous wastes \\
\hline & $\begin{array}{l}\text { 40 CFR 302, "Designation, Reportable } \\
\text { Quantities, and Notification" }\end{array}$ & $\mathrm{X}$ & $\begin{array}{l}\text { Identifies the allowable release limits of } \\
\text { hazardous and radioactive constituents }\end{array}$ \\
\hline
\end{tabular}


HNF-EP-0476 Rev. 2

\begin{tabular}{|c|c|c|c|}
\hline Agency/originator & Regulation, standard, or permit & $\begin{array}{l}\text { Applicable to } \\
\text { facility }\end{array}$ & Summary/application \\
\hline \multirow[t]{2}{*}{$\begin{array}{l}\text { ANSI, New York, } \\
\text { NY }\end{array}$} & $\begin{array}{l}\text { N 13.1", "Guidance to Sampling } \\
\text { Airborne Radioactive Materials in } \\
\text { Nuclear Facilities" }\end{array}$ & $\bar{X}$ & $\begin{array}{l}\text { Sets standards for effluent monitoring } \\
\text { systems }\end{array}$ \\
\hline & $\begin{array}{l}\text { N 42.18*, "Specification and } \\
\text { Performance of On-Site } \\
\text { Instrumentation for Continuously } \\
\text { Monitoring Radioactivity in Effluents" }\end{array}$ & $\mathrm{X}$ & $\begin{array}{l}\text { Recommendations for the selection of } \\
\text { instrumentation for the monitoring of } \\
\text { radioactive effluents }\end{array}$ \\
\hline \multirow{7}{*}{$\begin{array}{l}\text { Washington State } \\
\text { Department of } \\
\text { Ecology, Olympia, } \\
\text { WA }\end{array}$} & $\begin{array}{l}\text { WAC 173-216, "State Waste Discharge } \\
\text { Permit Program" }\end{array}$ & $\mathrm{X}$ & $\begin{array}{l}\text { Governs discharges to ground and surface } \\
\text { waters }\end{array}$ \\
\hline & $\begin{array}{l}\text { WAC } 173-220, \text { "National Pollutant } \\
\text { Discharge Elimination System Permit" }\end{array}$ & N/A & $\begin{array}{l}\text { Governs wastewater discharges to navigable } \\
\text { waterways; controls NPDES permit process }\end{array}$ \\
\hline & $\begin{array}{l}\text { WAC } 173-303, \text { "Dangerous Waste } \\
\text { Regulations" }\end{array}$ & $\overline{\mathrm{X}}$ & $\begin{array}{l}\text { Regulates dangerous wastes; prohibits direct } \\
\text { release to soil columns }\end{array}$ \\
\hline & $\begin{array}{l}\text { WAC } 173.400 \text {, "General Regulations } \\
\text { for Air Pollution Sources" }\end{array}$ & $\mathrm{X}$ & $\begin{array}{l}\text { Sets emissions standards for hazardous air } \\
\text { pollutants }\end{array}$ \\
\hline & $\begin{array}{l}\text { WAC 173-401, "Air Operating Permit } \\
\text { Program" }\end{array}$ & $\bar{X}$ & $\begin{array}{l}\text { Establishes an operating permit for hazardous } \\
\text { (regulated) air pollutants, including } \\
\text { radionuclides }\end{array}$ \\
\hline & $\begin{array}{l}\text { WAC } 173-460 \text {, "Control for New } \\
\text { Sources of Toxic Air Pollutants" }\end{array}$ & $\mathrm{X}$ & $\begin{array}{l}\text { Sets standards or new sources of toxic air } \\
\text { pollutants }\end{array}$ \\
\hline & $\begin{array}{l}\text { WAC 173-480, "Washington State } \\
\text { Ambient Air Quality Standard and } \\
\text { Emission Limits for Radionuclides" }\end{array}$ & $\mathrm{X}$ & $\begin{array}{l}\text { Endorses the } 10 \text { mrem/year EDE-EPA } \\
\text { standards ( } 40 \text { CFR } 61 \text {, Subpart H) }\end{array}$ \\
\hline \multirow{2}{*}{$\begin{array}{l}\text { Washington State } \\
\text { Department of } \\
\text { Health, Olympia, } \\
\text { WA }\end{array}$} & $\begin{array}{l}\text { WAC 246-247, "Radiation Protection - } \\
\text { Air Emissions" }\end{array}$ & $\mathrm{X}$ & $\begin{array}{l}\text { Sets standards for registration, permitting, } \\
\text { notification, new sources, review, } \\
\text { monitoring, and reports }\end{array}$ \\
\hline & "Notice of Construction" & $\mathrm{X}$ & If Applicable. \\
\hline EPA & $\begin{array}{l}\text { FF-01, "Radioactive Airborne } \\
\text { Emissions" }\end{array}$ & $\mathrm{X}$ & $\begin{array}{l}\text { Collective emissions from registered sources } \\
\text { shall meet the emissions requirements of } \\
\text { WAC } 173-480\end{array}$ \\
\hline $\begin{array}{l}\text { Benton Clean Air } \\
\text { Authority, } \\
\text { Richland, WA }\end{array}$ & Regulation 1 & $\overline{\mathrm{X}}$ & $\begin{array}{l}\text { Regulates air quality regarding compliance } \\
\text { with } 40 \text { CFR } 61, \text { Subpart } M \text {, for asbestos and } \\
\text { open burning. }\end{array}$ \\
\hline
\end{tabular}

$\mathrm{EDE}=$ effective dose equivalent

$\mathrm{N} / \mathrm{A}=$ not applicable.

*Referenced in DOE Orders and EPA regulations.

\subsubsection{State Operating Permit Program (40 CFR 70)}

This regulation defines the minimum elements required by the Federal Water Pollution Control Act of 1972 for state operating permit programs and corresponding standards and procedures by which the administrator approves, oversees, and withdraws approval of state operating permit programs.

\subsubsection{Identification and Listing of Hazardous Waste (40 CFR 261)}

This regulation identifies solid waste subject to regulation as a hazardous waste. 


\subsubsection{Designation, Reportable Quantities, and Notification (40 CFR 302)}

This regulation designates hazardous substances and identifies reportable quantities and notification requirements for release of these hazardous substances under the Comprehensive Environmental Response, Compensation, and Liability Act (CERCLA) of 1980 and the Safe Drinking Water Act of 1974, as amended.

Any unpermitted release of any of these designated hazardous substances must be reported. Therefore, if the possibility exists for a facility to release any of the designated substances, waste streams must be monitored for their presence and monitoring practices must be provided in a FEMP.

\subsection{INDUSTRY STANDARDS UNDER AMERICAN NATIONAL STANDARDS INSTITUTE}

The primary objective for sampling airborne radioactivity in effluents is to measure the release of radioactive materials to the environment. This is accomplished through sampling near the point of . release. The objective of ANSI N13.1 is to set forth the principles that apply in obtaining valid samples of airborne radioactive materials and to prescribe acceptable methods and materials for gaseous and particulate sampling. Performance-based sampling allows the use of single point sampling, i.e., a shrouded probe.

The objective of continuously monitoring instrumentation is to measure the quantity and/or the rate of release of radionuclides in the effluent stream and to provide useful documentation for scientific and logical purposes.

This standard applies to continuous monitors that measure normal releases, detect inadvertent releases, show general trends, and annunciate radiation levels that have exceeded predetermined values. This standard specifies detection capabilities, physical operating limits, reliability, and calibration requirements and sets forth minimum performance requirements for effluent monitoring.

\subsection{WASHINGTON STATE REGULATIONS}

Applicable Washington State regulations are discussed in the following sections.

\subsubsection{Air Operating Permit Program (WAC 173-401)}

The provisions in this regulation establish the element of a comprehensive Washington State air operating permit program consistent with the requirements of the Federal Clean Air Act of 1977. All sources (hazardous and radionuclides pollutants) subject to this regulation will have a permit to operate that ensures compliance with all applicable requirements.

\subsubsection{Ambient Air Quality Standards and Emission Limits for Radionuclides (WAC 173-480)}

Although the standard for Washington State establishes a 25 -mrem per year (cumulative) dose limit for public exposure to radionuclide emissions, facilities must comply with the most restrictive of federal, state, or local law. Therefore, the exposure limit that must be complied with is 10 mrem per year for the 
air pathway. Compliance is calculated for the nearest offsite receptor in an unrestricted area where any member of the public could be located (fence boundary).

\subsubsection{Radiation Protection - Air Emissions (WAC 246-247)}

This regulation specifies new source review, notification, registration, and permitting requirements associated with any source of radioactive air emissions in Washington State, including those on the Hanford Site. One requirement listed in WAC 246-247 is the semiannual reporting of emissions from each registered stack or vent onsite. By agreement with Washington State Department of Health, only annual reporting is required.

\subsubsection{State Waste Discharge Permit Program (WAC 173-216)}

This program governs discharges to ground and surface waters.

\subsubsection{Dangerous Waste Regulations (WAC 173-303)}

Any release of a dangerous or hazardous substance (as designated by WAC) to the environment, except permitted releases, must be reported. Waste streams that have the potential to contain dangerous waste constituents must be monitored accordingly.

\subsection{LOCAL REGULATIONS}

The local air pollution control authority (Benton Clean Air Authority) has jurisdiction over all air emissions except radionuclide emissions in Benton County areas, including the Hanford Site. Currently, there are no local standards more restrictive than the previously mentioned federal and state limits; therefore, federal and state standards apply.

WAC 173-480, "Ambient Radionuclides", defines maximum allowable levels for radionuclides in the ambient air and defines required levels for control of emissions.

While both WAC 246-247 and 173-480 list outdated maximum EDE standards, each contains a caveat stating that more stringent federal standards take precedence over the EDE standards specified by the WAC. Therefore, each effectively endorses the $10 \mathrm{mrem}$ per year EDE standard of NESHAP (40 CFR 61), Subpart H. 


\section{HNF-EP-0476 Rev. 2}

This page intentionally left blank. 


\subsection{IDENTIFICATION AND CHARACTERIZATION OF EFFLUENT STREAMS}

Both liquid and gaseous effluent streams exist at PFP. This section describes each effluent stream identified in WHC-EP-0440. Focus is placed on the 291-Z-1 Stack effluent, which is currently the only PFP source exceeding the FEMP criteria. Many of the liquid streams, identified in WHC-EP-0440 as having a potential for creating a contamination release, have been eliminated as sources. This effectively has eliminated the stream identified as $216-Z-20$ from the list of effluents requiring a FEMP. Furthermore, the effluent discharged to the French drains is not contaminated. The French drains potentially are contaminated. French drains are being managed as discussed in DOE/RL-96-40. The PFP east and west sanitary sewer lines were modified to form a common discharge to the Washington State permitted 2607-W1 tile field. The east and west tile fields are inactive and will be abandoned. The $216-Z-13$ French drain is isolated from its source and is no longer a soil column discharge point.

None of the following streams meet the FEMP effluent criteria.

- 200 Area TEDF effluent (formerly $216-Z-20$ crib and 216-Z-21 seepage basin)

- East tile field [sanitary sewer line (inactive)]

- West tile field [sanitary sewer line (inactive)]

- French drains.

Table 4-1 summarizes the constitution of each liquid effluent stream and describes the streams and the associated facilities.

The main existing gaseous effluent streams from PFP are as follows:

- 291-Z-1 Main Stack

- 234-5Z Building Zone 1 Exhaust

- 296-Z-3 Stack for the 241-Z Building

- 296-Z-5 Stack for the 2736-ZB Building

- 296-Z-6 Stack for the 2736-Z Building

- 296-Z-14 Stack for the 232-Z Building

- 296-Z-15 Stack for the 243-Z Building.

Only the 291-Z-1 Stack meets the FEMP criteria. Table 4-2 summarized the constitution of each gaseous effluent stream and describes each stream and the associated facilities.

The following sections describes the source terms that actually or potentially contribute to the PFP effluent streams during routine or upset operating conditions. Details are provided only for those streams for which the FEMP criteria were determined to be exceeded (WHC-EP-0440).

\subsection{1-Z-1 MAIN STACK ROUTINE OPERATING CONDITIONS}

Seven major systems contribute to this effluent stream:

- 234-5Z Building E-3 (Zone 3) exhaust system

- 234-5Z Building E-4 (Zone 4) exhaust system

- Process solution transfer vacuum exhaust

- PFP air sampling vacuum exhaust system 
- 236-Z Building E-3 exhaust system

- 236-Z Building E-4 exhaust system

- 236-Z Building air sampling vacuum system.

These systems include exhaust from areas that have a slight potential for radioactive contamination (designated as "Zone 3" areas) or are potentially contaminated or known to be contaminated (designated as "Zone 4 " areas).

Hazardous materials that might be released from the 291-Z Stack include trace quantities of oxides of nitrogen (NOx). Future stabilization campaign activities could result in emissions of styrene. For radioactive materials, data in DOE/RL-99-41 indicated that approximately $1.6 \times 10^{-4}$ curies of plutonium-239/240 was released from the 291-Z-1 Stack for calendar year 1998. This stack contributed $2.2 \times 10^{-4} \mathrm{mrem}$, or approximately 0.57 percent of the total Hanford Site 1998 EDE to the total calendar year 1998 dose of $3.8 \times 10^{-2} \mathrm{mrem}$. The average 291-Z-1 Stack flow rate averaged 250,000 cubic feet per minute with a standard deviation of 4 percent.

\section{$4.2 \quad 291-Z-1$ MAIN STACK UPSET OPERATING CONDITIONS}

The only releases identified for upset conditions would be small amounts of various chemicals from spillage of material or equipment failure. The most recent upset condition to occur at PFP involved the May 14, 1997 pressurization of a chemical makeup tank in the PRF that resulted in a violent rupturing of the tank. Emissions of nitrogen oxides were estimated (given the quantity of chemicals in the tank) as high as 35 pounds via the $291-\mathrm{Z}-1$ Stack. Before this event, the most significant upset release occurred in 1986, when hydrogen fluoride damaged a HEPA filter bank. This release is irrelevant to this FEMP because hydrogen fluoride is no longer used in PFP operations. No other significant upset releases have been identified that could affect the postulated release scenarios for upset conditions. 
HNF-EP-0476 Rev. 2

Table 4-1. Plutonium Finishing Plant Complex Liquid Effluent Streams.

\begin{tabular}{|c|c|c|c|c|c|}
\hline $\begin{array}{l}\text { Discharge } \\
\text { designation }\end{array}$ & Facilities serviced & $\begin{array}{l}\text { Liquid waste } \\
\text { description }\end{array}$ & $\begin{array}{c}\text { Hazardous } \\
\text { chemical content }\end{array}$ & $\begin{array}{c}\text { Radioactive } \\
\text { material content }\end{array}$ & Comments* \\
\hline $\begin{array}{l}200 \text { Area } \\
\text { TEDF }\end{array}$ & $\begin{array}{l}234-5 Z, 291-Z, \\
236-Z, 2736-Z B\end{array}$ & $\begin{array}{l}\text { Condensates, air } \\
\text { condition systems, } \\
\text { storm drains, etc. }\end{array}$ & $\begin{array}{l}\text { Normally } \\
\text { uncontaminated }\end{array}$ & $\begin{array}{l}\text { Normally } \\
\text { uncontaminated } \\
\left({ }^{90} \mathrm{Sr},{ }^{137} \mathrm{Cs},\right. \\
{ }^{238} \mathrm{Pu},{ }^{239} \mathrm{Pu}, \\
\left.{ }^{241} \mathrm{Pu},{ }^{241} \mathrm{Am}\right)\end{array}$ & $\begin{array}{l}\text { No radioactive } \\
\text { or hazardous } \\
\text { release } \\
\text { potential }\end{array}$ \\
\hline $\begin{array}{l}216-Z-14 \\
\text { French drains }\end{array}$ & $291-Z$ & ET-9 Exhaust Fan & None & $\begin{array}{l}\text { Normally } \\
\text { Uncontaminated }\end{array}$ & $\begin{array}{l}\text { No radioactive } \\
\text { release } \\
\text { potential }\end{array}$ \\
\hline $\begin{array}{l}216-Z-15 \\
\text { French drains }\end{array}$ & $291-Z$ & $\begin{array}{l}\text { S-11 and S-12 } \\
\text { evaporator cooler } \\
\text { drainage }\end{array}$ & None & $\begin{array}{l}\text { Normally } \\
\text { uncontaminated }\end{array}$ & $\begin{array}{l}\text { No radioactive } \\
\text { release } \\
\text { potential }\end{array}$ \\
\hline
\end{tabular}

* Details are provided in WHC-EP-0440. 
HNF-EP-0476 Rev. 2

Table 4-2. Plutonium Finishing Plant Complex Gaseous Effluent Streams.

\begin{tabular}{|l|l|l|l|l|l|}
\hline \multicolumn{1}{|c|}{$\begin{array}{c}\text { Discharge } \\
\text { designation }\end{array}$} & \multicolumn{1}{|c|}{$\begin{array}{c}\text { Facilities } \\
\text { serviced } \\
\text { desfluent } \\
\text { description }\end{array}$} & $\begin{array}{l}\text { Gazardous } \\
\text { material content }\end{array}$ & $\begin{array}{l}\text { Radioactive } \\
\text { material content }\end{array}$ & Comments \\
\hline $\begin{array}{l}\text { Building Zone 1 } \\
\text { exhausts }\end{array}$ & $234-5 Z$ & $\begin{array}{l}\text { Exhaust from } \\
\text { building 'clean' } \\
\text { areas }\end{array}$ & None & None & $\begin{array}{l}\text { No hazardous } \\
\text { potential }\end{array}$ \\
\hline $\begin{array}{l}291-Z-1 \text { Main } \\
\text { Stack }\end{array}$ & $234-5 Z, 236-Z$, & $\begin{array}{l}\text { Main filtered } \\
\text { effluent } \\
\text { discharge }\end{array}$ & $\begin{array}{l}\text { NOx, HCl, } \\
\text { acetone: trace } \\
\text { quantities }\end{array}$ & $\begin{array}{l}\text { Pu and } \\
\text { associated } \\
\text { radionuclides }\end{array}$ & $\begin{array}{l}\text { Hazardous } \\
\text { potential }\end{array}$ \\
\hline $296-Z-3$ Stack & $241-Z$ & $\begin{array}{l}\text { Building } \\
\text { exhaust } \\
\text { quantities }\end{array}$ & $\begin{array}{l}\text { Pu and } \\
\text { associated } \\
\text { radionuclides }\end{array}$ & $\begin{array}{l}\text { Extremely low } \\
\text { hazardous } \\
\text { potential }\end{array}$ \\
\hline $296-Z-5$ Stack & $2736-Z B$ & $\begin{array}{l}\text { Building } \\
\text { exhaust }\end{array}$ & None & $\begin{array}{l}\text { Pu and } \\
\text { associated } \\
\text { radionuclides }\end{array}$ & $\begin{array}{l}\text { Extremely low } \\
\text { hazardous } \\
\text { potential }\end{array}$ \\
\hline $296-Z-6$ Stack & $2736-Z$ & $\begin{array}{l}\text { Storage vault } \\
\text { exhaust }\end{array}$ & None & $\begin{array}{l}\text { Pu and } \\
\text { associated } \\
\text { radionuclides }\end{array}$ & $\begin{array}{l}\text { Extremely low } \\
\text { hazardous } \\
\text { potential }\end{array}$ \\
\hline $296-Z-14$ Stack & $232-Z$ & $\begin{array}{l}\text { Incinerator } \\
\text { exhaust }\end{array}$ & None & $\begin{array}{l}\text { Pu and } \\
\text { associated } \\
\text { radionuclides }\end{array}$ & $\begin{array}{l}\text { Extremely low } \\
\text { hazardous } \\
\text { potential }\end{array}$ \\
\hline $296-Z-15$ Stack & $243-Z$ & $\begin{array}{l}\text { Low-Level } \\
\text { Waste } \\
\text { Treatment } \\
\text { Facility }\end{array}$ & None & $\begin{array}{l}\text { Pu and } \\
\text { associated } \\
\text { radionuclides }\end{array}$ & $\begin{array}{l}\text { Extremely low } \\
\text { hazardous } \\
\text { potential }\end{array}$ \\
\hline
\end{tabular}

'Details are provided in WHC-EP-0440.

${ }^{2}$ This stack went on line after WHC-EP-0440 was issued. Therefore, the effluent data are taken from recent record samples and a stack assessment. 


\subsection{EFFLUENT POINT OF DISCHARGE DESCRIPTION}

This section characterizes the effluent discharge points within PFP for those effluent streams exceeding the criteria for requiring a FEMP. This characterization includes the identification of all contributing streams, physical dimensions, identification of any monitoring systems, flow rates, and other pertinent information. Information on the streams that did not exceed the criteria was documented in WHC-EP-0440.

\subsection{TEDF DISCHARGE}

200 Area TEDF is a permitted water discharge facility located in the 200 East Area. 200 Area TEDF consists of a monitoring and sampling facility and a 6-acre evaporative/percolation pond. 200 Area TEDF receives wastewater from facilities in the 200 Areas. All facilities in the 200 Areas have implemented BAT/AKART as required under the WAC 173-216 Discharge Permit. Each facility conducts monitoring and sampling before discharging to the 200 Area TEDF piping network.

The discharge from PFP to the 200 Area TEDF is made up of three separate streams that combine to constitute the total discharge. The water collected by the transport system flows through a series of pipes and septic/sewercovers and the 225-WC Sampling Facility to the 200 Area TEDF pump station where water is pumped to the 200 East Area for disposal. The three separate streams that combine to make up the total discharge are (1) effluent from the LLWTF, (2) roof drains on the 234-5Z Building and backside storm drains, and (3) front side steam condensate and HVAC cooling water. Operations and facilities serviced by this system include 234-5Z, the Analytical Laboratory in 234-5Z, the Development Laboratory in 234-5, and the 236-Z and 291-Z Buildings. Maintenance covers, numbered Z-I through $Z-4, Z-7, C-1$ through $C-4$, and S-1 through S-7, are located along the stream route to the interface point of PFP and 200 Area TEDF (refer to Figure 5.1).

The LLWTF receives wastewater from maintenance cover $Z-4$. The sources of water to $Z-4$ include 234-5Z, the 234-5Z Engineering Laboratory, the 234-5Z Development Laboratory, 236-Z, and the 29i-Z Exhaust Air Stack Building. The $232-Z$ and $242-Z$ Buildings have all drain lines plugged and water sources shut off, except for fire service water.

The 234-5Z roof drains and storm drains collect at maintenance covers Z-1 and Z-2. HVAC condensate water also is received from the $2736-Z B$ Building at $Z-1$. The wastewater collected by this system flows to Z-7, where the wastewater combines with the effluent from the LLWTF.

The front side steam condensate and HVAC cooling water joins the combined stream at C-2. The major contributor to this effluent is the steam condensate and spray pan water overflow from the 234-5Z Building supply fans.

The nominal flowrate for this system is approximately 30 gallons per minute with an allowable rate of 700 gallons per minute. As mentioned previously, the interface point between PFP and 200 Area TEDF is the 225-WC Sampling Facility. The maintenance covers serve as locations for obtaining grab samples of any stream flowing into each maintenance cover. Grab samples also can be taken from the LLWTF, which has composite samplers on the inlet and outlet to the facility stream. Grab samples can be collected periodically as a backup to the record sampling system or for special analysis of the stream constituents. 


\section{$5.2 \quad 291-Z-1$ MAIN STACK}

The PFP Main Stack, constructed of reinforced concrete, is 200 feet tall with an inside diameter of 16.5 feet at the base and 13.5 feet at the top. The stack exhausts filtered process and ventilation air from gloveboxes and hoods in the 234-5Z, 236-Z, and 242-Z Buildings, and from those rooms that have a slight potential for contamination. Systems that contribute to this effluent stream include the 234-5Z Building E-3 and E-4 exhaust and process solution transfer vacuum exhaust; the PFP air sampling vacuum exhaust system; and the 236-Z Building E-3 and E-4 exhaust and air sampling vacuum exhaust systems. Depending on the source, air passes through from one to three testable stages of HEPA filtration before entering the stack. The stack is equipped with an air sampling probe located at the 50 -foot level of the stack. The probe feeds a record sampler and an alpha continuous air monitor (CAM) with an alarm.

The flowrate from the stack averages approximately 250,000 cubic feet per minute as determined by ventilation and balance personnel. Four of seven exhaust fans operate at any one time, with the remaining three as standby plus two steam-driven turbines for power-loss emergency operation. 
HNF-EP-0476 Rev. 2

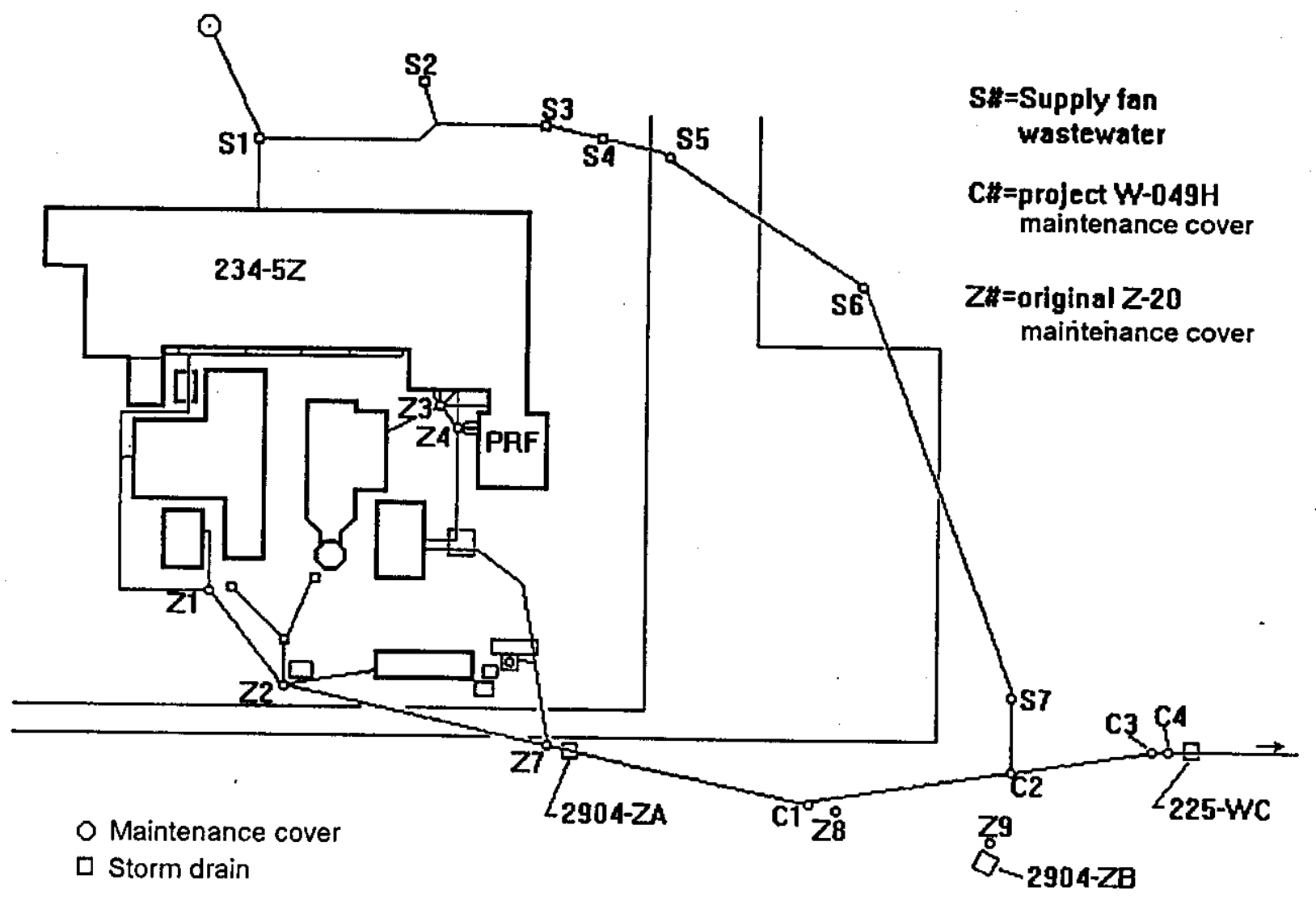

Figure 5-1. Plan and Overall Piping Schematic for the 200 Area TEDF Effluent Stream. 
HNF-EP-0476 Rev. 2

This page intentionally left blank. 


\subsection{EFFLUENT MONITORING/SAMPLING SYSTEM DESIGN CRITERIA}

This section presents design criteria for both liquid and gaseous effluent monitoring systems. These include criteria contained in federal regulations including DOE Orders 5400.1 and 5400.5, and design criteria used by the contractor to ensure compliance with the regulations and 200 Area TEDF State Waste Discharge Permit requirements.

The design criteria pertaining to the PFP stack effluent CAM systems are contained in ANSI N42.18. The design criteria pertaining to the record sampling systems include ANSI N13.1.

\subsection{LIQUID EFFLUENTS}

DOE has maintained that the release of radioactive materials is governed by the Atomic Energy Act of 1954 and that the release limits set by DOE correspond to federally permitted releases and are thus exempt from other federal and state regulations. At the same time, DOE has committed to complying with all 'applicable' limits of EPA and state regulations.

DOE Order 5400.5 provides guidance on the acceptable levels of radioactivity that are allowed in liquid waste and effluents. The purpose of the DOE Orders is to ensure that the dose to the public remains below $100 \mathrm{mrem}$ per year and protects the environment.

Demonstration of compliance with DOE Order 5400.5 is based on data from monitoring and surveillance programs. DOE Order 5400.5 states that liquid effluents from DOE activities shall not cause private or public drinking water systems downstream of the facility discharge to exceed the drinking water limits in 40 CFR 141. There is no guidance given on how to achieve that goal with regard to allowed concentrations in the facility liquid effluent.

The following guidance is provided in Chapter II, Section 3 of DOE Order 5400.5, for surface discharges.

- Discharges greater than DCG values on an annual average would require a BAT be applied.

- Discharges at less than DCG do not require implementation of a BAT.

- The settable solids in any liquid effluent stream cannot exceed 5 picocuries per gram alpha or 50 picocuries per gram beta.

- Interim dose limits for native aquatic animal organisms cannot exceed I radiation absorbed dose per day.

Guidance on discharges of liquid waste to aquifers and phase out of soil columns are found in DOE Order 5400.5, Chapter II, 3.b. The guidance is limited to a re-affirmation of the DOE commitment to phase out soil column use (i.e., trenches, cribs, ponds, and drain fields). In addition, new or increased discharges of radionuclides in liquid waste to soil columns is prohibited (Chapter II, 3.b[2]) unless DOE activity cannot comply or the release is tritium (Chapter II, 3.e[1]).

Compliance with the dose limits of DOE Order 5400.5 are demonstrated by documentation of an appropriate combination of measurements and calculation. The ALARA concept in DOE Order 5400.1 
is to attain dose levels as low as technically and economically feasible. Compliance with these two objectives would seem to require monitoring any stream with the potential for containing measurable radioactivity.

\subsection{GASEOUS EFFLUENTS}

Specific criteria for upgrading the Major (potential EDE exceeding 0.1 mrem per year) Stacks on the Hanford Site to meet recent regulations were documented in the NESHAPs Federal Facility Compliance Agreement (FFCA) (DSI 9401181). These criteria were intended to be used for upgrading sampler-monitor systems on selected stacks. The 291-Z-1 Main Stack was included as a Major Stack and meets the criteria identified in the NESHAPs FFCA.

Generally, ANSI N13.1 continues to serve as the primary source of detailed requirements for effluent monitoring systems endorsed in the regulations. Therefore, comparison of the existing stack monitoring systems to these design criteria is made in Section 14.0 of this FEMP.

The following general design and performance criteria are applicable to all radioactive gaseous effluent streams at PFP. Further detail is provided in HNF-PRO-450, "Air quality - Radioactive Emissions," Section 2.2. In Section 7.0 of this FEMP, the effluent monitoring system instrumentation is described in detail. This information was used to demonstrate compliance with both the criteria and applicable regulations in Section 14.0 of this FEMP.

- Continuous sampling is provided for all gaseous effluents that have the potential to exceed $0.1 \mathrm{mrem}$ per year EDE to the offsite individual. For sources with a potential less than or equal to $0.1 \mathrm{mrem}$ per year, periodic confirmatory sampling will be performed. (Basis 40 CFR 61.93).

- CAM and an alarm system are provided for PFP stack systems. The CAM systems are not intended to satisfy the $40 \mathrm{CFR} 61$, Subpart $\mathrm{H}$, requirements.

- Audible and visible alarm indications easily are discernible to responsible personnel in continuously or frequently occupied spaces.

- Monitoring system alarms are set at release concentrations as low as possible without resulting in an excessive number of false alarms because of normal fluctuations in emissions or background radiation levels.

- Air monitoring systems are calibrated according to ANSI N323 and ANSI N42-18 when installed and anytime the systems are subject to maintenance or modification.

- Air monitoring systems are powered from a source that has the same or equivalent back-up capability as the air mover for the effluent stream being monitored.

- Air monitoring systems are inspected daily and source-checked monthly.

- Analytical methods for continuous monitoring of effluents are in accordance with applicable EPA methods for the contaminants specified by the EPA. Alternate methods are used where approved EPA methods are not specified. 
HNF-EP-0476 Rev. 2

\subsection{CHARACTERIZATION OF CURRENT EFFLUENT MONITORING SYSTEM}

This section characterizes the existing effluent monitoring systems for those effluent discharge points previously determined to require a FEMP (the 291-Z-1 Main Stack). These characterizations include a description of the instrumentation and any applicable technical specifications or operational safety requirements.

\subsection{INSTRUMENTATION DESCRIPTION}

This section contains detailed descriptions of the effluent monitoring instrumentation for the 291-Z-1 Stack. These descriptions and the design criteria presented in Section 6.0 are used in this FEMP to determine compliance with applicable regulations.

The 291-Z-Main Stack is equipped with an air sampling probe system feeding a record sampler and an alpha CAM with an alarm. Details on the stack sampling and monitoring equipment are provided in the following text. A more detailed description of the stack can be found in WHC-EP-0541.

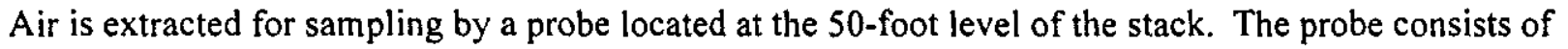
six nozzles branching from a single 300 -series stainless steel sample delivery line. The collection probe spans the diameter of the stack with the nozzles centered in six equal annular areas. The probe delivers the sample to a 300-series stainless steel flow splitter for record and CAM samples at a flowrate of 0.11 cubic meter per minute. A sample transport line extends approximately 1 meter horizontally from the stack surface connection flange to the monitoring instruments located within an adjacent elevated instrument cabinet.

The instrument cabinet also is located outside of the stack at the 50-foot level. This arrangement facilitatès the use of a straight, short sampling line, thus minimizing potential losses in the sampling line. Line losses associated with the record sampler have been estimated at 5 percent with filter losses contributing an estimated 9 percent. This represents a total overall correction factor of 0.86 . Stack effluent monitoring equipment located in the instrument cabinet (2712-Z Building) includes the following:

- Incoming sample line

- Record sample holder

- Two rotameters

- Two vacuum gauges

- Vacuum lines

- Two flow regulators

- Exhaust line routed back into the stack

- Flow splitter

- Alpha CAM

- Flow totalizer

- Two vacuum switches

- Two centrifugal type pumps

- Alarm relay panel.

Inside the instrument cabinet, a baseboard heater heats the sample transport line to inhibit condensation by maintaining the temperature above the dew point. Line length and tube transition severities are 
minimized. Once extracted, the sample passes through a flow splitter and is divided into two equal parts: the record sample loop and the CAM loop.

The first line exiting the splitter directs an air sample to a record sampler assembly at a rate of 2 cubic feet per minute, which collects particulate radionuclides. The record sampler is a 47 -millimeter fixed-head sampler and is located approximately 8 inches after the splitter. The sampler assembly holds a membrane filter composed of acrylic copolymer cast on a non-woven nylon substrate, which is good for collecting 0.3 -micrometer size particles with a 91 percent collection efficiency. The record sampler provides a representation of the amount of radioactive particulate being discharged. The filter media are analyzed biweekly for gross alpha and gross beta activities, as described in Section 9.0, and composited for quarterly analysis of specific radionuclide concentrations. The air passes through a flow totalizer that measures total flow in increments of 0.1 cubic meter. The record sampler/flow totalizer system allows radionuclide discharge concentrations to be determined and provides the basis for reporting. The sample air travels through an air rotameter, a vacuum gauge, an adjustable vacuum switch, and an oil-less pump regulated by a flow regulator. The vacuum switch monitors the vacuum in the line and triggers an alarm when pressure outside of a specified range occurs, indicating a loss of flow. The sample air is routed back into the stack.

The second line exiting the splitter leads to a CAM. The CAM loop collects particulate matter in a fashion similar to that of the record sampler, but the CAM monitors for elevated radioactivity on the filter. This instrument also provides backup capability for the record sampler. The CAM is calibrated annually by Pacific Northwest National Laboratory (PNNL). The airflow through the CAM is maintained at approximately 2 cubic feet per minute. The CAM is equipped with alarms indicating high radiation levels or inoperability. The vacuum system serving the CAM is similar to that serving the record sampler except that there is no flow totalizer and the rotameter is an integrated CAM component.

The 291-Z-1 Stack monitoring and sampling system alarms sound remotely in Room 714 of the 234-5Z Building, These alarms include CAM high radiation, CAM fail, and vacuum pump fail. The stack CAM alarms also sound locally at the $2712-\mathrm{Z}$ Building where the stack monitoring equipment is located.

There have been no significant modifications to this system since a final acceptance test was conducted January 30,1979 on the $291-Z$ effluent monitoring system.

Functional testing of the 291-Z-1 Stack sampler and monitoring system components is performed monthly and annual calibrations are performed. Components that are part of the calibration cycle include the CAM, vacuum gauges, vacuum switches, rotameters, and the flow totalizer. Components involved in the functional testing cycle include the CAM, vacuum switches, rotameters, and totalizer. Recall of components for preventative maintenance action is accomplished by the PFP Preventative Maintenance and Surveillance system. This process is the same for the other PFP stack monitoring and sampling systems. The system can be used to facilitate recall of historical records of maintenance performed as required.

Operability surveillance of the monitoring and sampling equipment is performed each shirt. When routine sample exchanges are required (every 2 weeks), both surveillance and exchange inspections are performed. In the event of a vacuum pump failure, a health physics technician replaces the failed pump and restores the system to an operable status. 
HNF-EP-0476 Rev. 2

\subsection{TECHNICAL SPECIFICATIONS PERTAINING TO THE EFFLUENT MONITORING SYSTEM (EMS)}

PFP stack CAM operability requirements are presented in Table 7-1.

Surveillance requirements associated with operability are as follows:

- VERIFY each stack CAM sample flow rate is 2.0 cubic feet per minute +20 percent (1.6-2.4 cubic feet per minute). Minimum frequency is daily.

- VERIFY each stack CAM alarm set point is less than the equivalent of 20,000 DCG-hour ( 135 counts per minute). Minimum frequency is daily.

- Perform FUNCTIONAL TEST of each stack alpha monitoring instrument and its associated failure and high concentration alarm. Minimum frequency is monthly.

- CALIBRATE each stack alpha monitoring instrument. Minimum frequency is annually.

The stack CAMs perform passive functions, which are to detect airborne radioactive material and activate alarms should the alarm set point on the CAM be exceeded. CAMS do not provide an active function, which would actuate equipment or systems to prevent or mitigate an accident. In most cases, the CAMs would not serve to reduce the consequences associated with a release of airborne radioactive material as most accidents involve a sudden release of material over a short period. Potentially chronic releases from process operations are due to equipment failures (e.g., failed filters) and tend to be small in nature. If these releases are sufficient to actuate the CAMs, operator action generally is adequate to limit the release so there is no significant consequence.

The PFP stack record samplers also play an integral role in recognizing out-of-specification release trends. Facility health physics personnel remove the record samples every 2 weeks for analysis at the Waste Sampling and Characterization Facility (WSCF). Data are retrieved from a computer database [ABCASH (Automated Bar Coding of Air Samples at Hanford)]. Any adverse trends can be recognized and acted upon by PFP personnel.

Downtime limit requirements are in place for the record sampling and CAM systems. If a system failure occurs, loss-of-record sampling capabilities are expected to be corrected as quickly as practicable.

Details on the effluent monitoring equipment and alarms are provided in Table 7-2. All equipment is located in the 2712-Z Building, which is the 50 -foot elevated sampling station for the stack. The alarm annunciator windows are located in Room 714 of the 234-5Z Building. 
HNF-EP-0476 Rev. 2

This page intentionally left blank. 
HNF-EP-0476 Rev. 2

Table 7-1. Plutonium Finishing Plant Stack Continuous Air Monitor Operability Requirements.

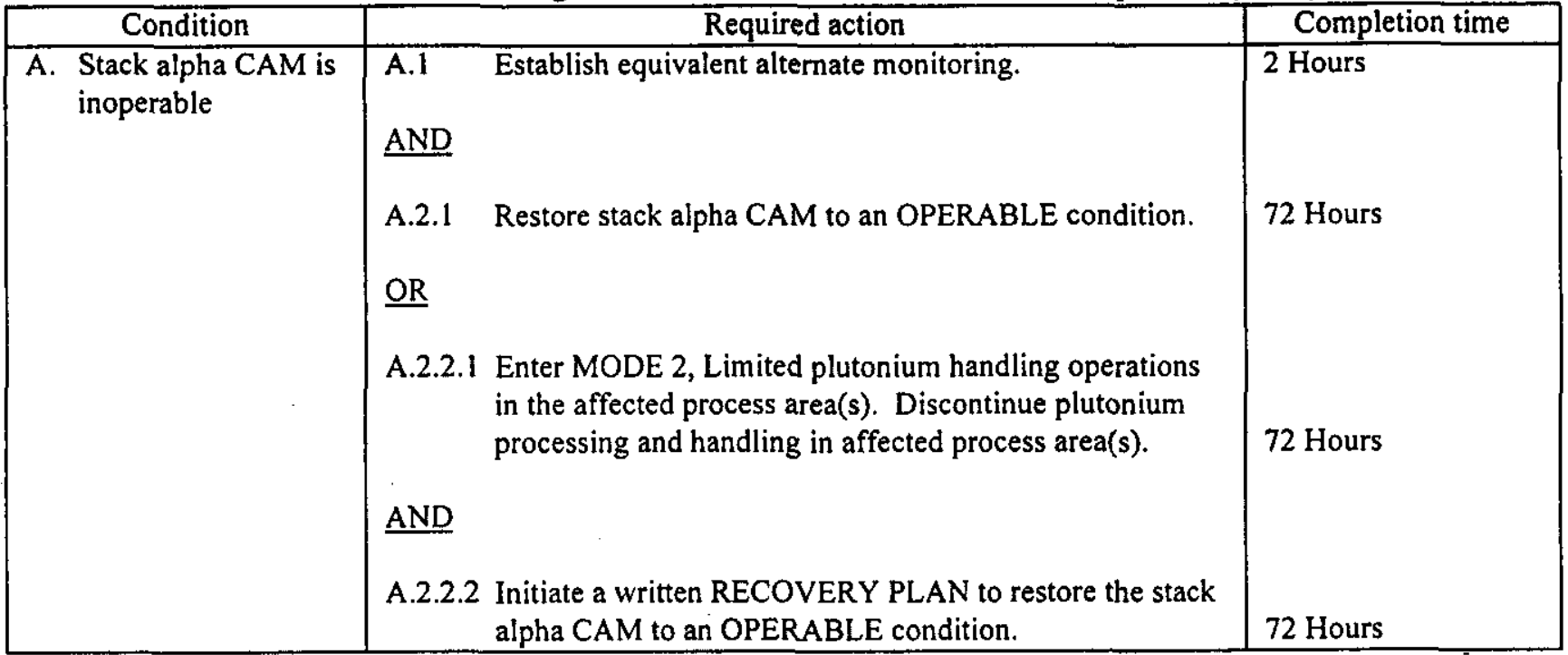


Table 7-2. Monitoring Instrumentation for Gaseous Effluent System, 291-Z-1 Stack.

\begin{tabular}{|c|c|c|}
\hline Instrument type & $\begin{array}{c}\text { Maintenance frequency and } \\
\text { type }\end{array}$ & Alarm set points \\
\hline $\begin{array}{l}\text { FQ-SPL-Z1 } \\
\text { Stack flow totalizer }\end{array}$ & $\begin{array}{l}\text { Annual calendar and monthly } \\
\text { functional test }\end{array}$ & N/A \\
\hline $\begin{array}{l}\text { VS-SPL-Z1 } \\
\text { Stack sampler vacuum alarm } \\
\text { switch }\end{array}$ & $\begin{array}{l}\text { Annual calendar and monthly } \\
\text { functional test }\end{array}$ & $\begin{array}{l}\text { Low alarm } 3 " \mathrm{Hg} \\
\text { High alarm 9" } \mathrm{Hg}\end{array}$ \\
\hline $\begin{array}{l}\text { VS-CAM-Z1 } \\
\text { Stack CAM vacuum alarm } \\
\text { switch }\end{array}$ & $\begin{array}{l}\text { Annual calendar and monthly } \\
\text { functional test }\end{array}$ & $\begin{array}{l}\text { Low alarm 3" } \mathrm{Hg} \\
\text { High alarm 9" } \mathrm{Hg}\end{array}$ \\
\hline $\begin{array}{l}\text { PI-CAM-Zl } \\
\text { Stack CAM vacuum gauge }\end{array}$ & Annual calendar & N/A \\
\hline $\begin{array}{l}\text { PI-SPL-Z1 } \\
\text { Stack sampler vacuum gauge }\end{array}$ & Annual calendar & N/A \\
\hline $\begin{array}{l}\text { FI-CAM-Z1 } \\
\text { CAM rotameter }\end{array}$ & Annual calendar (by PNNL) & N/A \\
\hline $\begin{array}{l}\text { FI-SPL-Z1 } \\
\text { Record sampler rotameter }\end{array}$ & Annual calendar & N/A \\
\hline $\begin{array}{l}\text { CAM-Z1 } \\
\text { Continuous air monitor }\end{array}$ & $\begin{array}{l}\text { Annual calendar (by PNNL) } \\
\text { and monthly functional test }\end{array}$ & $30-40 \mathrm{cpm}$ \\
\hline $\begin{array}{l}\text { ANN-714-W1 } \\
\text { Stack CAM high-radiation } \\
\text { alarm }\end{array}$ & Monthly functional test & $30-40 \mathrm{cpm}$ \\
\hline $\begin{array}{l}\text { ANN-714-W2 } \\
\text { Stack CAM failure alarm }\end{array}$ & Monthly functional test & $0 \mathrm{cpm}$ \\
\hline $\begin{array}{l}\mathrm{ANN}-714-\mathrm{W} 3 \\
\mathrm{CAM} \text { vacuum alarm }\end{array}$ & Monthly functional test & $\begin{array}{l}\text { Low alarm 3" } \mathrm{Hg} \\
\text { High alarm 9" } \mathrm{Hg}\end{array}$ \\
\hline $\begin{array}{l}\text { ANN-714-W4 } \\
\text { sampler vacuum alarm }\end{array}$ & Monthly functional test & $\begin{array}{l}\text { Low alarm } 3 " \mathrm{Hg} \\
\text { High alarm 9" } \mathrm{Hg}\end{array}$ \\
\hline
\end{tabular}

$\mathrm{cpm}=$ counts per minute. 
HNF-EP-0476 Rev. 2

\subsection{HISTORICAL MONITORING/SAMPLING DATA FOR EFFLUENT STREAMS}

This section presents recent monitoring and sampling data for the PFP effluent streams. A discussion also is provided that relates these data with future projected emissions.

\subsection{NORMAL CONDITIONS}

This section presents detailed monitoring and sampling data for the past 5 years of published data for the 291-Z-1 Stack. These data have been retrieved from annual reports (e.g., DOE/RL-99-41). A comparison of the available data to both the current and future expected release quantities is provided based on the current status of operations and any future plans for the facilities.

\subsubsection{Radioactive Releases}

Sample data for the 291-Z-1 Stack and other PFP stacks is maintained in the ABCASH database. A unique electronic data processing (EDP) code identifier designates each sample location. The 291-Z-1 stack record sample is identified by Z810 and the CAM is identified by Z811. Each individual sample also is given a unique identification number. Tables $8-1$ and $8-2$ provide historical radiological data based on annual summaries.

The 291-Z-1 Stack flow currently is measured yearly. The measurements are made for ventilation system knowledge and not for emission reporting purposes. The stack flowrate currently is assumed to be 290,000 cubic feet per minute for emission reporting purposes. Current methods entail doing pitot flow measurement traverses of various tributary ducts to the stack and summing these, thus arriving at total stack flow. Recently (1996-1998), these measurements indicated that normal operating flow is approximately 250,000 cubic feet per minute. Between 1979-1989, stack flows averaged 230,000 cubic feet per minute with a 6 percent $(+/-14 K)$ standard deviation. Between $1991-1994$, flows averaged 250,000 cubic feet per minute with a 4 percent $(+/-10 \mathrm{~K})$ standard deviation.

Future processing operations were discussed in Section 2.2 of this FEMP, which included a list of approved stabilization alternatives for plutonium-bearing materials at the PFP. Doses to the offsite MEI are not expected to change significantly as a result of these planned operations. The MEI hypothetically is assumed to reside for the entire year at a point 25 kilometers east of PFP. The final PFP stabilization EIS (DOE/EIS-0244F) projected a conservative upper bound dose estimate of $0.15 \mathrm{mrem}$ to the MEI. Actual doses are expected to be much lower. The NESHAP emission limit is 10 mrem per year to the MEI. Table 8-3 provides a summary of the dose estimates for 5 years, as published in annual environmental release reports. The $291-Z-1$ Stack currently contributes approximately 15 percent of the total estimated Hanford Site dose. As indicated from the reported dose estimates, the Hanford Site, and therefore PFP, are orders of magnitude lower than the emission limit.

\subsubsection{Nonradioactive Releases}

The only routine nonradioactive substance historically released from the 291-Z-1 Stack that exceeded reportable quantities was $\mathrm{CCI} 4$, which was released during past PRF operations. However, the PRF process has been shut down. CCI4 is not used in any operating process at PFP, and there are no plans for use in future operations. Small quantities of hydrogen fluoride have been released routinely during past 
operations, but future operations will not involve the use of hydrogen fluoride. On May 14, 1997, a chemical makeup tank in PRF pressurized and resulted in a violent rupturing of the tank. Emissions of nitrogen oxides were estimated (given the quantity of chemicals in the tank) as high as 35 pounds by way of the 291-Z-1 Stack, and possibly through two small holes in the roof of PRF created during the event.

The following are the primary alternatives for each of the plutonium-bearing inventory categories with the expected emission constituents. The information is taken from the PFP stabilization EIS (DOE/EIS-0224F). The final stack release rates are based on conservative assumptions to bound the maximum release rates of plutonium and gases. The release rates are continuous averages for the process described.

- Plutonium-bearing solutions

- Ion exchange: no air emissions

- Vertical calcination: Nitrogen oxides (9.8 E-3 grams per second). A ceramic filter and a scrubber unit remove essentially all particulate matter

- Muffle furnace (thermal stabilization): PM10 (2.3 E-8 grams per second)

- Oxides, fluorides, and process residues: Thermal stabilization using muffle furnaces: PM10 (3.3 E-8 grams per second)

- Metals and alloys: Repackaging followed by thermal stabilization: PM10 (2.8 E-8 grams per second)

- Polycubes and combustibles: Pyrolysis: PM10 (2.8 E-9 grams per second), styrene (7.4 E-4 grams per second), carbon monoxide (1.7 E-3 grams per second).

The expected air contaminants fall into two categories of regulated pollutants: specifically, criteria pollutants (carbon monoxide, nitrogen dioxide, and particulate matter) and a hazardous air pollutant (styrene). The emitted particulate matter would be emitted as very fine particulates after HEPA filters filter the exhaust air. The emitted particulate matter therefore would be referred to as PM10 (particles less than 10 microns in size). A portion of the PM10 includes plutonium oxide. The release rates shown previously represent small process exhausts, compared with many industrial process exhausts.

Ground-level concentrations of these contaminants were estimated by using an atmospheric dispersion model. The maximum downwind contaminant concentrations projected by the computer model were compared to ambient air standards. When these concentrations, added to measured background levels, were compared with the applicable ambient air standards, all of the downwind concentrations were found to be significantly lower than the standards. Therefore, impacts from the alternatives mentioned were found to be insignificant. The increase in criteria air pollutant emissions from the stabilization alternatives are below the significant rates listed by Ecology. For further detail on these findings, refer to DOE/EIS-0244F. 
HNF-EP-0476 Rev. 2

\subsection{UPSET CONDITIONS}

The most recent upset condition to occur at PFP involved the May 14, 1997 pressurization of a chemical make-up tank in PRF (refer to Section 8.1.2). No other significant upset releases have been identified that could affect the postulated release scenarios for upset conditions. 
HNF-EP-0476 Rev. 2

This page intentionally left blank. 
Table 8-1. Annual Average Concentration (microcuries per milliliter) for 291-Z-1 Stack 1994-1998.

\begin{tabular}{|l|l|l|l|l|l|}
\hline \multicolumn{1}{|c|}{ Radionuclide } & \multicolumn{1}{|c|}{1994} & \multicolumn{1}{c|}{1995} & \multicolumn{1}{c|}{1996} & \multicolumn{1}{c|}{1997} & \multicolumn{1}{c|}{1998} \\
\hline Pu 238 & $4.3 \mathrm{E}-15$ & $4.5 \mathrm{E}-16$ & $9.6 \mathrm{E}-16$ & $5.0 \mathrm{E}-16$ & $7.7 \mathrm{E}-16$ \\
\hline Pu 239,240 & $8.6 \mathrm{E}-14$ & $1.5 \mathrm{E}-14$ & $4.0 \mathrm{E}-14$ & $2.1 \mathrm{E}-14$ & $3.6 \mathrm{E}-14$ \\
\hline Pu 241 & $5.7 \mathrm{E}-13$ & $3.9 \mathrm{E}-14$ & $8.1 \mathrm{E}-14$ & $1.1 \mathrm{E}-14$ & $1.0 \mathrm{E}-14$ \\
\hline Am 241 & $1.6 \mathrm{E}-14$ & $2.9 \mathrm{E}-15$ & $8.6 \mathrm{E}-15$ & $4.7 \mathrm{E}-15$ & $7.0 \mathrm{E}-15$ \\
\hline Total alpha & $8.9 \mathrm{E}-14$ & $2.4 \mathrm{E}-14$ & $4.1 \mathrm{E}-14$ & $2.4 \mathrm{E}-14$ & $4.6 \mathrm{E}-14$ \\
\hline Total beta & $4.6 \mathrm{E}-15$ & $1.9 \mathrm{E}-15$ & $3.8 \mathrm{E}-15$ & $2.8 \mathrm{E}-15$ & $3.9 \mathrm{E}-15$ \\
\hline
\end{tabular}


Table 8-2. Annual Emissions (Curies) for 291-Z-1 Stack 1994-1998.

\begin{tabular}{|l|l|l|l|l|l|}
\hline \multicolumn{1}{|c|}{ Radionuclide } & \multicolumn{1}{|c|}{1994} & \multicolumn{1}{c|}{1995} & \multicolumn{1}{c|}{1996} & \multicolumn{1}{c|}{1997} & \multicolumn{1}{c|}{1998} \\
\hline P 238 & $1.5 \mathrm{E}-5$ & $2.3 \mathrm{E}-6$ & $4.2 \mathrm{E}-6$ & $2.2 \mathrm{E}-6$ & $3.4 \mathrm{E}-6$ \\
\hline Pu 239,240 & $3.0 \mathrm{E}-4$ & $7.6 \mathrm{E}-5$ & $1.7 \mathrm{E}-4$ & $9.3 \mathrm{E}-5$ & $1.6 \mathrm{E}-4$ \\
\hline Pu 241 & $2.0 \mathrm{E}-3$ & $2.0 \mathrm{E}-4$ & $3.5 \mathrm{E}-4$ & $4.6 \mathrm{E}-5$ & $4.4 \mathrm{E}-5$ \\
\hline Am 241 & $5.5 \mathrm{E}-5$ & $1.5 \mathrm{E}-5$ & $3.7 \mathrm{E}-5$ & $2.0 \mathrm{E}-5$ & $3.0 \mathrm{E}-5$ \\
\hline Total alpha & $3.1 \mathrm{E}-4$ & $1.2 \mathrm{E}-4$ & $1.8 \mathrm{E}-4$ & $1.1 \mathrm{E}-4$ & $2.1 \mathrm{E}-4$ \\
\hline Total beta & $1.6 \mathrm{E}-5$ & $9.5 \mathrm{E}-6$ & $1.7 \mathrm{E}-5$ & $1.2 \mathrm{E}-5$ & $1.6 \mathrm{E}-5$ \\
\hline
\end{tabular}


HNF-EP-0476 Rev. 2

Table 8-3. Hanford Site Dose Estimate For Point Source Emissions.

\begin{tabular}{|c|c|}
\hline Calendar year & $\begin{array}{c}\text { Effective dose equivalent } \\
\text { (millirem) }\end{array}$ \\
\hline 1994 & 0.005 \\
\hline 1995 & 0.0029 \\
\hline 1996 & 0.0020 \\
\hline 1997 & 0.0012 \\
\hline 1998 & 0.0013 \\
\hline
\end{tabular}


HNF-EP-0476 Rev. 2

This page intentionally left blank. 


\subsection{SAMPLE ANALYSIS}

Sample analysis and sample management are discussed in this section.

\subsection{ANALYTICAL LABORATORY AND PROCEDURES}

The analytical laboratory procedures for the FEMP activities are identified in two quality assurance project plans (QAPjP), and the annual statement of work as follows:

- WHC-EP-0446-2, Quality Assurance Project Plan for the Facility Effluent Monitoring Plan Activities

- HNF-EP-0528-3, NESHAP Quality Assurance Project Plan for Radioactive Airborne Emissions

- HNF-EP-0835-5, Statement of Work for Services Provided by the Waste Sampling and Characterization Facility for the Effluent and Environmental Program during Calendar Year 1999.

\subsubsection{Record Sample Exchange}

The operations group taking the sample initiates sample identification. Sampling personnel use the ABCASH system to provide electronic sample identification and chain of custody. Sample custody is transferred when the analytical laboratory receives the properly marked sample.

Along with all the samples, which are taken from the gloveboxes, the record sampler filter paper, and the CAM, sample filters are sent to an analytical laboratory. Record and sample filters are exchanged per PFP specified methods.

\subsubsection{CAM Filter Exchange}

CAM filters are exchanged per PFP specified methods.

\subsubsection{Sample Data Examination and Delivery}

Sample data examination and delivery to the analytical laboratory follow onsite methods.

\subsubsection{Laboratory Sample Analysis Instructions}

EDP codes are assigned to each discharge point monitoring and sampling equipment units. Minimum detectable concentrations are provided in Table 9-1. 


\subsubsection{Laboratory Analysis}

When the sample reaches WSCF, the record sample is held for 7 days to allow the short-lived natural-occurring isotopes to decay. The sample is counted for alpha and beta readings. These readings are documented and placed in storage for further sampling. Quarterly, these samples are gathered and dissolved for radio-isotopic analysis. The results of these analyses are reported annually. The CAM samples are not treated as record samples unless specifically requested.

The sample analysis services provided by WSCF are defined in a statement of work for services provided by WSCF published annually (e.g., HNF-EP-0835).

\subsubsection{Laboratory Procedures}

The analytical laboratory procedures are identified in Sections 5.0 and 5.1 of HNF-EP-0528-3.

\subsection{SAMPLE AND DATA TRACKING}

Tracking of samples and sample data are governed by ABCASH. Tracking of radioactive airborne emissions sample data is controlled through assignment of unique EDP codes for each sample location. These EDP codes are used by WSCF personnel to report the results in accordance with the QAPjP for radioactive emissions data.

\subsection{U.S. DEPARTMENT OF ENERGY ANALYTICAL AND LABORATORY GUIDELINES}

The analytical and laboratory procedures for the FEMP activities are identified in Section 8.0 of WHC-EP-0446. General requirements for laboratory procedures, data analyses, and statistical treatment are addressed in Table 9-2.

The following elements identified in DOE/EH-0173T are addressed in WHC-SD-CP-QAPP-017 and WHC-SD-CP-QAPP-002:

- Procedures preventing cross contamination

- Documentation of methods

- Gamma emitting radionuclides

- Calibration

- Handling of samples

- Analysis method and capabilities

- Gross alpha, beta, and gamma measurements

- Direct gamma-ray spectrometry
- Beta counters

- Alpha-energy analysis

- Radiochemical separation procedures

- Reporting of results

- Counter calibration

- Inter-calibration of equipment and procedures

- Counter background

- Quality assurance. 
HNF-EP-0476 Rev. 2

Table 9-1. Minimum Quantifiable Concentrations for Specific Radionuclides as Measured in Bi-Weekly Air Samples.

\begin{tabular}{|c|c|}
\hline Radionuclide & $\begin{array}{c}\text { Minimum quantifiable } \\
\text { concentration (microcuries per } \\
\text { milliliter) }\end{array}$ \\
\hline $239,240 \mathrm{~Pa}$ & $2.0 \times 10^{-15}$ \\
\hline $238 \mathrm{Pu}$ & $2.0 \times 10^{-15}$ \\
\hline $241 \mathrm{Am}$ & $1.9 \times 10^{-15}$ \\
\hline $89,90 \mathrm{Sr}$ & $1.9 \times 10^{-14}$ \\
\hline $106 \mathrm{Ru} \mathrm{Rh}$ & $3.4 \times 10^{-13}$ \\
\hline
\end{tabular}


HNF-EP-0476 Rev. 2

Table 9-2. Data Analyses and Statistical Treatment.

\begin{tabular}{|l|l|}
\hline \multicolumn{1}{|c|}{ Element } & \multicolumn{1}{|c|}{ Documentation } \\
\hline $\begin{array}{l}\text { Summary of data and statistical treatment } \\
\text { requirements }\end{array}$ & HNF-SD-CP-QAPP-017 \\
\hline Variability of effluent and environmental data & HNF-EP-0527-8 \\
\hline Summarization of data and testing for outliers & $\begin{array}{l}\text { Statistical identification of control standards are } \\
\text { performed by the Laboratory Measurement } \\
\text { Control System database program during the } \\
\text { annual review of data for setting control limits. } \\
\text { Outliers are evaluated. }\end{array}$ \\
\hline Treatment of significant figures & HNF-SD-CP-QAPP-017 \\
\hline Parent-decay product relationships & $\begin{array}{l}\text { Parent-decay product relationships are not } \\
\text { accounted for in laboratory operating procedures. }\end{array}$ \\
\hline $\begin{array}{l}\text { Comparisons to regulatory or administrative } \\
\text { control standards and control data }\end{array}$ & $\begin{array}{l}\text { WSCF participates in the EPA Intra-Comparison } \\
\text { Program }\end{array}$ \\
\hline Quality assurance & HNF-SD-CP-QAPP-017 \\
\hline
\end{tabular}


HNF-EP-0476 Rev. 2

\subsection{NOTIFICATION AND REPORTING REQUIREMENTS}

Notifications and reporting of specific events related to environmental releases and/or events involving effluents and/or hazardous materials are made according to DOE Orders 5400.1 and 5000.3B. Specific implementation, where required, is included in the appropriate occurrence categorization, notification, and reporting procedures.

\subsection{OCCURRENCE IDENTIFICATION AND IMMEDIATE RESPONSE}

Personnel will identify events and conditions and promptly notify management of such occurrences.

- Call 911 if immediate help such as fire, ambulance, or Hanford Patrol is required.

- Call 373-3800 (Patrol Operations Center) if assistance other than fire, ambulance, or Hanford Patrol is required.

- After requesting necessary outside assistance, personnel will notify the supervisor, who will notify the facility manager, the building emergency director, and the Occurrence Notification Center (ONC) (376-2900).

Operations personnel will take appropriate immediate action to stabilize or return the facility/operation to a safe condition. Actions taken in response to nonroutine releases as evidenced by high sample results from liquid and gaseous effluent sampling will be documented.

The oversight organizations will notify the DOE-RL of the event after receiving notifications from, and discussing the event with, the facility manager.

\subsection{OCCURRENCE CATEGORIZATION}

Occurrences (environmental) are categorized as soon as practical using specific onsite criteria. 
HNF-EP-0476 Rev. 2

This page intentionally left blank. 
HNF-EP-0476 Rev. 2

\subsection{INTERFACE WITH NEAR-FACILITY MONITORING}

DOE/RL-91-50 documents two distinct but related components; environmental surveillance conducted by PNNL and effluent monitoring conducted by the FH. Environmental surveillance consists of surveillance of all environmental parameters to demonstrate compliance with regulations. Effluent monitoring includes both in-line and facility effluent monitoring as well as near-facility environmental monitoring. Projected EDEs, reported in this FEMP, are the products of effluent monitoring.

\subsection{PURPOSE}

Near-facility monitoring (NFM) provides facility-specific environmental monitoring to protect the environment adjacent to facilities under the responsibility of $\mathrm{FH}$ and to ensure compliance with federal, state, and local environmental regulations.

The objectives of NFM are to evaluate the following:

- Compliance with DOE, EPA, Ecology, WDOH, and internal FH team environmental radiation protection requirements and guides

- Performance of radioactive waste confinement systems.

- Trends of radioactive materials in the environment at and adjacent to nuclear facilities and waste disposal sites.

Specifically, NFM is developed to:

- Moñitor all inactive, existing, and new low-level waste disposal sites to assess both radiological and nonradiological hazards (DOE Order 5820.2A)

- Determine the effectiveness of effluent treatment and controls in reducing effluents and emissions (DOE/EH-0173T)

- Detect and quantify unplanned releases (DOE/EH-0173T, 40 CFR 302, WAC 173-303-145, and DOE 5484.1)

- Monitor fugitive emissions and diffuse sources from contaminated areas for compliance with NESHAPs (40 CFR 61 and DOE/EH-0173T), Toxic Air Emissions Inventory (40 CFR 265, Subparts AA \& B13), State Operating Permit Program (40 CFR 70), and Source Registration (WAC 246-247)

- Monitor all surplus facilities before decontaminating or decommissioning (DOE Order 5820.2A)

- Monitor new and existing sites, processes, and facilities for potential impacts and releases (DOE Order 5484.1 and DOE/EH-0173T)

- Monitor and assess radioactive contamination and potential exposure to employees and the public (DOE Orders 5400.1 and 5400.5). 
NFM provides a level of assurance to $\mathrm{FH}$ that the effluent and contamination controls for the various facilities and waste sites are effective.

\subsection{MEDIA SAMPLED}

Media include ambient air, surface water, groundwater, external radiation dose, soil, sediment, vegetation, and animals at or near active and inactive facilities and/or waste sites. Parameters monitored include the following, as needed: $\mathrm{pH}$, water temperature, radionuclides, radiation exposure, and hazardous constituents. Animals that are not contaminated, as determined by a field instrument survey, are released to a nonhazardous environment.

Samples are collected from known or suspected effluent pathways (e.g., downwind of potential releases, liquid streams, or proximal to release points). To avoid duplication, $\mathrm{FH}$ relies on existing sample locations where PNNL previously established sample sites (e.g., air samplers in the 300 Area). There are approximately (numbers and locations can vary year to year) 60 air samplers, 300 external radiation monitor points (survey points and thermoluminescent dosimeter), 160 soil sample sites, and 95 vegetation sample sites. Animal samples are collected at or near facilities and/or waste sites.

Sampler design (e.g., air monitors) will be reviewed at least biannually to determine equipment efficiency and compliance with current EPA and industry (e.g., ANSI and American Society for Testing and Materials (ASTM)) standards.

Surveys to detect surface radiological contamination are conducted near and on liquid waste disposal sites (e.g., cribs, trenches, drains, retention basin perimeters, pond perimeters, and ditch banks), solid waste disposal sites (e.g., burial grounds and trenches), unplanned release sites, tank farm perimeters, stabilized waste disposal sites, roads, and firebreaks. There are 391 sites where radiological surveys are conducted: 100 in the 100 Areas, 273 in the 200/600 Areas, and 18 in the 300/400 Areas.

NFM will be reviewed at least annually to determine that the appropriate effluents are being monitored and that the monitor locations are in position to best determine potential releases.

\subsection{COMMUNICATION}

FH and PNNL will compare and communicate results of their respective monitoring programs at least quarterly and as soon as possible under upset conditions.

Results of NFM are published in annual reports. The radionuclide values in these reports are expressed in curies, or portions thereof, for each radionuclide per unit weight of sample (e.g., picocuries per gram) or in field instrument values (e.g., counts per minute). Values are reported in this manner, rather than EDE, which is calculated as the summation of the products of the dose equivalent received by specified tissues of the body and a tissue-specific weighting factor. 
HNF-EP-0476 Rev. 2

\subsection{QUALITY ASSURANCE (QA)}

HNF-EP-0528-3 describes the QA requirements associated with NESHAP compliance. The QAPjP is consistent with the requirements in DOE Order 5700.6C, NQA-1, and EPA QA/R-5. In addition, QA requirements in 40 CFR 61 , Appendix $B$, Method 114, will be considered when performing monitoring calculations and establishing monitoring systems for airborne emissions.

\subsection{OBJECTIVE}

The objective of this plan is to provide a documented QA plan describing QA requirements for facilities implementing the FEMPs.

\subsection{REQUIREMENTS}

HNF-EP-0528-3 has been developed to implement the overall QA program requirements for radioactive airborne emissions data collection and reporting activities. The QAPjP applies specifically to field activities, laboratory analyses, and continuous monitoring performed for all FEMPs by FH. 


\section{HNF-EP-0476 Rev. 2}

This page intentionally left blank. 
HNF-EP-0476 Rev. 2

\subsection{INTERNAL AND EXTERNAL PLAN REVIEW}

DOE Order 5400.1, Chapter IV.4, requires that FEMPs be reviewed annually and updated every 3 years. The FEMP should be reviewed and updated as necessary after each major change or modification in the facility.

FH prepares an annual effluent discharges report for each area on the Hanford Site to cover both airborne and liquid release pathways. In addition, a report on the air emissions and compliance to the NESHAP is prepared by $\mathrm{FH}$ and submitted to the EPA as well as DOE Headquarters.

Facility management is required to obtain approval from FH for all changes to the FEMPs, including those generated during reviews and updates.

FH is responsible for assigning appropriate personnel to perform the reviews, assessments, and approvals as necessary, to ensure program integrity. 
HNF-EP-0476 Rev. 2

\subsection{COMPLIANCE ASSESSMENT}

Based on the information presented previously, there are no PFP effluent streams out of compliance with the requirement to provide monitoring. Furthermore, all radioactive and nonradioactive hazardous materials that potentially are released through these streams currently are being monitored if required. The 291-Z-1 is currently the only PFP stack that is required to meet the measurement requirements outlined under NESHAP (40 CFR 61, Subpart H). This stack was declared compliant with the NESHAP by EPA Region 10 in September 1995. 


\section{HNF-EP-0476 Rev. 2}

This page intentionally left blank. 
HNF-EP-0476 Rev. 2

This page intentionally left blank. 


\subsection{SUMMARY AND CONCLUSIONS}

This FEMP assessed the magnitude of routine and potential liquid and airborne effluent releases from the PFP Complex to determine the compliance of effluent monitoring systems and sampling programs with applicable federal, state, and local regulations. Based on the data reviewed, and according to regulations, the 291-Z-1 Stack was determined to require a monitoring plan according to the regulations. The adequacy and compliance of the monitoring systems or sampling programs are documented in this plan. Compliance was determined by comparing the existing systems and procedures to applicable regulations and accepted guidance. 
HNF-EP-0476 Rev. 2

This page intentionally left blank.

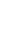




\subsection{REFERENCES}

ANSI N13.1, Sampling and Monitoring Releases of Airborne Radioactive Substances From the Stacks and Ducts of Nuclear Facilities, latest edition, Health Physics Society, McLean, Virginia.

ANSI N42.18, American National Standard Specification and Performance of On-Site Instrumentation for Continuously Monitoring Radioactivity in Effluents, latest edition, American National Standards Institute, New York, New York.

ANSI N323, Radiation Protection Instrumentation Test and Calibration, American National Standards Institute, New York, New York.

BWHC-9752393, External Memo, "243-Z Low Level Waste Treatment Facility 296-Z-15 Stack Assessment".

DOE/EIS-0244-F, Plutonium Finishing Plant Stabilization Final Environmental Impact Statement.

DOE/EH 173T, Environmental Regulatory Guide for Radiological Effluent Monitoring and Environmental Surveillance, U.S. Department of Energy, Washington, D.C.

DOE/EV/1830-T5, A Guide to Reducing Radiation Exposure to As Low As Reasonably Achievable (ALARA), U.S. Department of Energy, Washington, D.C.

DOE Order 5000.3B, Unusual Occurrence Reporting System, U.S. Department of Energy, Washington, D.C.

DOE Order 5400.1, General Environmental Protection Program, U.S. Department of Energy, Washington, D.C.

DOE Order 5400.5, Radiation Protection of the Public and the Environment, U.S. Department of Energy, Washington, D.C.

DOE Order 5480.4, Environmental Protection, Safety and Health Protection Standards, U.S. Department of Energy, Washington, D.C.

DOE Order 5484.1, Environmental Protection, Safety, and Health Protection, U.S. Department of Energy, Washington, D.C.

DOE Order 5700.6, Quality Assurance, U.S. Department of Energy, Washington, D.C.

DOE Order 5820.2A, Radioactive Waste Management, U.S. Department of Energy, Washington, D.C.

DOE/RL-96-40, Miscellaneous Streams Best Management Practices (BMP) Report.

DOE/RL-99-41, Radionuclide Air Emissions Report for the Hanford Site, 1998.

DSI No. 9401181 , NESHAPs Federal Facility Compliance Agreement.

HNF-3602 Volume 1: Calculating Potential to Emit Releases and Doses for FEMPS and NOC's. 
HNF-EP-0528-3, NESHAP Quality Assurance Project Plan for Radioactive Airborne Emissions

HNF-EP-0835-5, Statement of Work for Services Provided by the Waste Sampling and Characterization Facility for the Effluent and Environmental Program during Calendar Year 1999

HNF-SD-CP-QAPP-017, Waste Sampling Characterization Facility Quality Assurance Plan

WHC Correspondence 018C0-85-036, "Facility Effluent Monitoring Plan Determination for the Treated Effluent disposal Facility", L. P. Diediker to D. L. Flyckt, dated March 14, 1995.

WHC Memo 15540-94-MPB-164, "Request for Redesignation of Stack 296-Z-3", August 1994.

WHC-EP-0440, Facility Effluent Monitoring Plan Determination for the 200 Area Facilities

WHC-EP-0446-2, Quality Assurance Project Plan for the Facility Effluent Monitoring Plan Activities

WHC-EP-0491, Management Plan for Facility Effluent Monitoring Plan Activities

WHC-EP-0541, Plutonium Finishing Plant Comparison with 40 CFR 61, Subpart H, and Other Referenced Guidelines for Stack 291-Z-1

WHC-EP-0894, Hanford Site Radionuclide National Emission Standards for Hazardous Air Pollutants Registered and Unregistered Stack (Power Exhausi) Source Assessment, December 1995. 


\section{DISTRIBUTION}

U.S. Department of Energy, Richland Operations Office

J. B. Hall

P. J. Krupin

A5-15

R. S. Ollero

A5- 15

L. D. Romine

R3-79

Reading Room

R3-79

$\mathrm{H} 2-53$

Fluor Hanford

J.E. Bramson (5)

T5-54

R. C. Brunke

G1-37

W. E. Davis

Gl-37

L. P. Diediker

G1-27

T. P. Frazier (5)

G1-37

G. W. Jackson

T5-50

D. G. Ranade

$\mathrm{Gl}=37$

R. J. Swan

T5-54

W. R. Thackaberry

T4-52

L. F. Willis

$\mathrm{H} 8-73$

Lockheed Martin Services, Inc.

Central Files

B1-07

DPC

H6-08 
HNF-EP-0476 Rev. 2

This page intentionally left blank. 